\title{
Finansal Gelişme Üzerinde Politik Faktörlerin Etkisi: Az Gelişmiş ve Gelişmekte Olan Ülkelere Yönelik Bir Analiz
}

\author{
Finansal Gelişme Üzerinde Politik Faktörlerin Etkisi: Az \\ Gelişmiş ve Gelişmekte Olan Ülkelere Yönelik Bir Analiz
}

Öz

Bu çalışmanın amacı politik karar alma süreci ve aktörlerinin finansal gelişim üzerindeki etkisinin araştırılmasıdır. Politik faktörlerin etkisi, 'politik sistem ve meclis yapısı' ile 'politik istikrar' olmak üzere iki alt başlık altında gruplandırılan dokuz açıklayıcı değişken kullanılarak, 48 az gelişmiş ve gelişmekte olan ülkede 1985-2012 dönemi için dinamik panel veri analiz yöntemi ile incelenmiştir. Analiz sonuçları, demokratikleşme düzeyinin finansal gelişim üzerinde anlamlı ters-U şeklinde etkiye sahip olduğunu, hükümetin oy oranının finansal gelişim üzerinde olumlu, koalisyon şeklindeki hükümetlerin olumsuz etkisi olduğunu, yürütme organının yetkilerini sınırlayan kurum ve kuralların ise anlamlı bir etkisinin olmadığını göstermiştir. Politik istikrarı temsil eden değişkenler açısından elde edilen sonuçlar ise siyasi krizlerin, kabine değişim sıklığının, milletvekili seçimlerinin ve politik yolsuzluk düzeyinin finansal gelişimi engellediğini, hükümetin görev süresinin ise anlamlı bir etkisinin olmadığını göstermiştir.

Anahtar Kelimeler: Finansal Gelişme, Politik Faktörler, Panel GMM
The Effect of Political Factors on Financial Development: An Analysis of Less Developed and Developing Countries

\begin{abstract}
The aim of this study is to investigate the effects of political decision-making process and political actors on financial development. The impact of political factors was investigated in 48 underdeveloped and developing countries employing dynamic panel data analysis for 1985-2012 period, using nine explanatory variables grouped under two subheadings: 'the political system and parliamentary structure' and 'the political stability'. The results show that the level of democratization has significant inverse U-shaped effect on financial development. While the higher government votes increase the financial development, but coalition governments affect adversely. Institutions and rules that limit the powers of the executive have no significant effect on financial development. With regard to variables representing political stability, the results show that political crises, the frequency of cabinet changes, legislative elections and political corruption limit the financial development, while there is no significant effect of the government's term of office.
\end{abstract}

Keywords: Financial Development, Political Factors, Panel GMM

\section{Giriş}

Ekonomik karar birimlerinin ihtiyaçlarına cevap verebilen ve etkin işleyen finans sektörü kalkınma sürecinin temel unsurlarından birisidir. Ne var ki, yalnızca farklı ekonomik gelişme düzeyine sahip ülkeler arasında değil, benzer ülkeler arasında dahi varolan finansal gelişmişlik farklııklarının nedenleri literatürde önemli bir araştırma alanıdır. Bu noktada çalışmalar kurumsal kalite, politik yapı ve sosyal faktörler üzerinde yoğunlaşmıştır. Kurumsallaşma finans piyasalarının gelişiminde gerekli altyapıyı sağlama fonksiyonu açısından önem arz ederken, tüm

\footnotetext{
${ }^{1}$ Dr. Öğr. Üyesi, Erciyes Üniversitesi IỉBF, İşletme Bölümü, torunt@erciyes.edu.tr, yazar ORCID bilgisi: https://orcid.org/0000-0002-9157-2754.

${ }^{2}$ Doç. Dr., Erciyes Üniversitesi IïBF, Maliye Bölümü, mfilgun@erciyes.edu.tr, yazar ORCID bilgisi:

https://orcid.org/0000-0002-1305-2067.
} 
bu kararların alınma sürecini ifade eden politik yapının olası etki kanallarının da ayrı olarak incelenmesi gerekmektedir.

Politik yapı her biri finansal sistem üzerinde farklı etkiler oluşturabilecek çok boyutlu bir kavramdır. Ekonomik birimlerin taleplerinin devlet politikalarının şekillendirilmesindeki rolü anlamında demokratikleşme düzeyi başta olmak üzere, kısa vadeli ve taraflı kararların engellenmesi amacıyla politika yapıcıların yetkilerinin sınırlandırılması, hükümetin yapısal reformları gerçekleştirme güç ve iradesinin göstergeleri olarak meclis ve hükümet yapısı, uzun dönemli bir olgu olan finansal piyasaların gelişimine yönelik politikaların belirlenmesi noktasında belirleyici faktörlerdir. Bunun yanında hükümet değişimleri veya siyasi krizler gibi politik istikrarı bozan gelişmeler, belirsizliği artırarak reel ve finansal piyasaları etkileyebilmektedir.

Siyaset ve finansal değişkenler arasındaki ilişki medya ve karar birimleri tarafından tartışılan bir konu olmakla birlikte, etkileşime yönelik uygulamalı akademik çalışmalar sınırlıdır. Politik yapının farklı unsurlarının finansal gelişim üzerindeki olası etkilerinin tespit edilmesini gerektiren nedenler şu şekilde sıralanabilir. İlk olarak siyasi gelişmeler ve hükümet eylemleri, finansal piyasalarda dalgalanmalara yol açmak suretiyle toplumsal refahı etkileme potansiyeline sahiptir. İkincisi, ilişki kanallarının tespiti hem yatırımcılara hem de politika yapıcılara kararlarında rehberlik sağlayabilir. Diğer yandan yatırımcıların yüksek riske maruz kaldığı ve zararlı devlet müdahalesi ihtimalinin yüksek olduğu az gelişmiş ve gelişmekte olan ülkelerde, siyasi kararların ve belirsizliğin etkisinin daha fazla olması beklenebilir. Son olarak iktisat politikalarının şekillenmesinde uzun dönemli hedefler kadar karar alma süreci ve karar alıcıların tercihleri de rol oynamaktadır.

Yukarıda açıklanan motivasyonlar doğrultusunda bu çalışmanın amacı az gelişmiş ve gelişmekte olan ülkelerde politik yapının finansal gelişme üzerindeki etkisinin tespit edilmesidir. Çalışmanın finansal gelişimin bir bütün olarak ele alınması, politik yapının farklı unsurlarının bir arada incelenerek karşılaştırma imkanı sağlaması, demokratikleşme sürecinin asimetrik etkilerinin tartışılması noktasında literatüre katkı sağlaması amaçlanmaktadır. Çalışmanın bir sonraki bölümünde söz konusu ilişkinin teorik altyapısı açıklanacak, ardından literatürdeki uygulamalı çalışmalar hakkında bilgi verilecektir. Uygulama bölümünde, analizler 48 ülkeye ait 1985-2012 dönemi verileri ile seçilmiş dokuz politik değişken çerçevesinde dinamik panel veri yöntemiyle gerçekleştirilmiştir. Son kısımda elde edilen bulgular ışığında değerlendirme ve politika önerilerine yer verilmiştir.

\section{Teorik Çerçeve}

\subsection{Finansal Gelişmeyi Belirleyen Faktörler}

Gelişmiş bir finansal sistem, sürdürülebilir ve dengeli ekonomik büyümeyi sağlamada gerek şartlardan birisidir. Etkin işleyen finansal piyasalar, atıl tasarrufları harekete geçirerek, işlemleri kolaylaştırarak ve yabancı yatırımları çekerek fonlama yeteneğini artırır. Bu tür gelişmiş piyasalar finansal kaynakların daha etkin tahsisini, gelişmiş risk yönetimini, şeffaflık ve kurumsal yönetim uygulamalarını kolaylaştırır (Ayadi vd., 2015: 159). Yabancı sermaye girişini ve teknolojik yeniliği kolaylaştıran ve teşvik eden güçlü bir finansal sistem yüksek sermaye birikimini (yatırım oranını), ticaret hacmini, finansal riskten korunma ve sigorta hizmetlerini, çeşitlendirilmiş tasarruf ve portföy tercihlerini garanti eder. Aynı şekilde finansal gelişme yoksulluğun ve gelir eşitsizliğinin azaltılmasına, sermaye hareketliliğine, düşük gelirli kesimin 
finansal kaynaklara daha iyi erişimine, yüksek getirili yatırımlara, refahın yanısıra ekonomik büyümenin de artmasına imkan sağlamaktadır (Raza vd., 2014: 166).

Finansal gelişmenin ekonomik büyüme üzerindeki olumlu etkileri araştırmacıları finansal gelişmeyi belirleyen ve ülkeler arasındaki finansal gelişme farklılıklarına neden olan faktörleri araştırmaya teşvik etmiştir. Yapılan teorik ve ampirik çalışmalar ülkeler arasındaki finansal gelişme farklııklarının açıklanmasında kurumsallaşma, piyasaların dışa açıklığı, hukuk geleneği ve politik sistem başta olmak üzere finansal sistemi destekleyen çok sayıda içsel ve dışsal faktöre işaret etmektedir. Örneğin Girma ve Shortland (2008: 2) bazı ülkelerin diğerlerinden daha düşük finansal gelişim düzeyine sahip olmalarının sebeplerini üç kategoride toplamaktadır. Bunlardan birincisi, sözleşmelerin düzgün şekilde uygulanması ve finansal kurumların dürüst olarak faaliyet göstermesini sağlayan hukuki altyapının zayıf olduğu gerçeğidir. İkinci neden ülkelerin hukuk kökeni ile finansal gelişme arasındaki ilişkidir. Belirtilen üçüncü sebep ise bazı ülkelerde daha düşük finansal gelişmeye neden olan politik koşullardır. Voghouei, Azali ve Jamali (2011) ise finansal sistemin performansı üzerinde farklı faktörlerin etkilerini gösteren çalışmaları incelemişler ve finansal gelişmenin belirleyicilerini Şekil 1'de görüldüğü gibi sınıflandırmışlardır. Söz konusu değişkenler (i) makroekonomik faktörler (ii) hukuk kökeni, (iii) kurumlar, (iv) hükümet müdahelesi (finansal serbestleşme), (v) mal ve hizmet piyasalarında açıklık, (vi) finansal piyasaların açıklığı, (vii) politik faktörler ve (viii) kültür ve coğrafya gibi diğer faktörlerdir. Politik faktörler hem doğrudan hem de diğer belirleyiciler vasıtasıyla dolaylı etkilere sahip olduğundan, finansal gelişmede en etkili faktörlerden birisi olarak düşünülebilir. Ülkelerin siyasal yapılarındaki çeşitlilikler, ülkeler arası finansal gelişme farklııklarını açıklayabilmektedir. Dolayısıyla yazarların da belirttiği gibi finansal gelişmeyi en iyi şekilde teşvik edebilecek politikaları değerlendirmek için her bir politik belirleyicinin etkisinin kapsamlı bir şekilde incelenmesine ihtiyaç vardır. 
Şekil 1: Finansal Gelişmenin Belirleyicileri Diyagramı

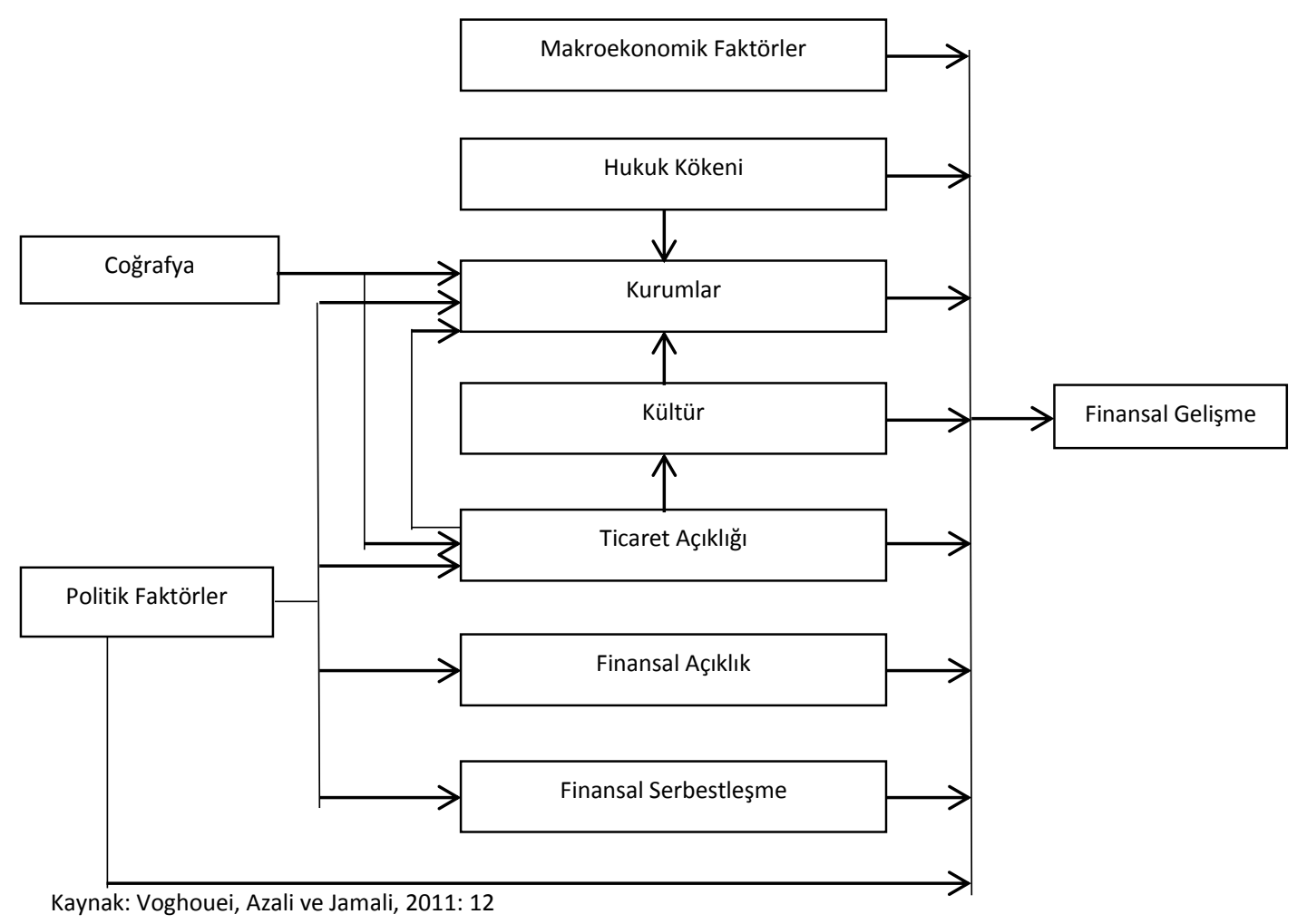

Şekil 1'de görüldüğü üzere makroekonomik faktörler finansal gelişmeyi doğrudan etkilemektedir. Litaratürde enflasyon, gelir, yatırım ve ekonomik büyüme gibi farklı makroekonomik değişkenlerin finansal gelişme üzerinde etkisi olduğunu kanıtlayan çok sayıda çalışma bulunmaktadır. Finansal gelişmeyi belirleyen faktörlerden bir diğeri ülkedeki hukuk orijinidir. La Porta vd. $(1997,1998)$ tarafından öne sürülen hukuk-finans hipotezine göre özel mülkiyet haklarının korunması finansal gelişmenin temelini oluşturmaktadır. Ülkelerin hukuk geleneklerini yasal kuralların kökeni belirlemektedir. Bu hipoteze göre Fransız medeni hukuk geleneğini benimsemiş ülkeler özel mülkiyet haklarının korunmasına daha az önem verme eğilimindedir ve bundan dolayı İngiliz genel hukuk geleneğini benimseyen ülkelerden daha düşük finansal gelişme seviyelerine sahiptir (Beck vd., 2003: 138-139).

Acemoğlu vd. (2005) tarafından geliştirilen donatım teorisi, ekonomik kurumlardaki farklılıkların ekonomik ve finansal gelişme düzeyinin temel belirleyicileri olduğunu ileri sürmektedir. Kurumsallaşma hukukun üstünlüğünü desteklediğinden, uzun dönemli yatırımların rasyonel olduğu bir ortam oluşturmaktadır (Bzhalava, 2014: 8). Kurumsal altyapı; kültürel kurumlar, yasal kurumlar, ekonomik kurumlar, politik kurumlar ve sosyal kurumlar olmak üzere dört grupta sınıflandırılmaktadır. Kültürel kurumlar norm ve inançlardan meydana gelir. Yasal kurumlar başta mülkiyet hakları olmak üzere kanunların yapılması ve uygulanması ile ilgilidir, ekonomik kurumlar ise üretim sürecini, mal ve hizmetlerin tahsis ve dağıtımını, piyasa performansını yöneten kuralları belirlerlemektedir. Politik rejimler ve yapısal kurallar ise politik kurumları oluşturmaktadır (Mandon ve Mathonnat, 2014: 5; Rachdi ve Mensi, 2012: 3). 
Kurumların finansal gelişmenin önemli belirleyicilerinden biri olduğu konusunda literatürde büyük ölçüde fikir birliği bulunmaktadır.

Finansal gelişmenin birinci dereceden belirleyicisi olan ekonomik kurumlar, belirli bir siyasi sistemdeki politik kurumların türü tarafından belirlenmektedirler. Politik kurumlar toplumda siyasi gücün dağılımını belirlemek suretiyle oradaki ekonomik kurumların türünü belirleyeceğinden, finansal gelişme sürecinin kökenindeki kurumsal kategori olarak görülmektedir. Zira kurumların organizasyonu ile ilgili kararlar da politik süreç tarafından gerçekleştirilmektedir. Böylelikle politik kurumlar nihayetinde uygulanan politikaların niteliğini ve yasal/kurumsal sistemin kalitesini açıklamaktadır (Mandon ve Mathonnat, 2014: 5).

Finansal serbestleşme de finansal sistemi uzun vadede desteklemektedir. Finansal serbestleşme; devlete ait bankaların ve finansal kurumların özelleştirilmesi, finans sektörüne serbest girişin garanti edilmesi, merkez bankasının bağımsızlığı, kredi kontrol araçlarının kaldırılması ve faiz oranları için esnek kontrol mekanizması uygulanması bileşenlerinin bir toplamı olarak tanımlanabilir (Bzhalava, 2014: 9). Finansal serbestleşmenin daha iyi kaynak tahsisine, yatırım seviyesinde artışa ve daha yüksek verimliliğe yol açması bu özelliklerine dayanmaktadır.

Dışa açıklığın finansal gelişmeyi etkilediğini gösteren ampirik çalışmalar bulunmaktadır. Bankacılık sektörü ve borsa üzerindeki etkileri farklı olsa da ticarette açıklık finansal gelişmeyi etkileyen önemli etmenlerden bir diğeridir (Voghouei, Azali ve Jamali, 2011: 12). Ayrıca Rajan ve Zingales (2003) mal, para ve sermaye piyasalarının eş zamanlı olarak dışa açılmasının başarılı finansal gelişmenin anahtarı olduğunu ileri sürmektedirler. Son olarak kültür ve coğrafya gibi diğer faktörler de ekonomik birimlerin tercih ve davranışları üzerinden finansal gelişme farklılıklarını belirlemektedir.

\subsection{Politik Faktörlerin Finansal Gelişme Üzerindeki Etkisi}

Yukarıda belirtildiği gibi finansal gelişmenin önemli belirleyicilerinden birisi politik faktörlerdir. Politik faktörler, finansal faaliyetler üzerindeki doğrudan etkilerinin yanısıra ekonomik kurumlar, yasal kurumlar, ticari ve finansal dışa açıklık ile finansal serbestleşme gibi diğer belirleyiciler aracılığıyla dolaylı etkilere de sahiptir (Voghouei, Azali ve Jamali, 2011: 12). Politik faktörler bir yandan uygulanacak politikaların, diğer yandan yasal ve kurumsal donanımların kaynağı olarak düşünülebilir. Gerçekte dinamik politik ekonomi çerçevesi ekonomik kurumları ve hukuk geleneklerini şekillendirmekte ve böylece ekonomik büyümeye ve finansal gelişmeye etki etmektedir (Voghouei, Azali ve Law, 2011: 77). Ayrıca seçimler, kabine yapıları, referandumlar ve yasama tartışmaları gibi politik süreçler hükümetlerin ekonomi politikalarını ve buna bağı olarak yatırım ortamının koşullarını belirlemektedir. Bu başlık altında politik altyapının farklı unsurlarının finansal gelişim üzerindeki etkisi incelenecektir.

Politik faktörlerin başında gelen yönetim sisteminin/siyasal rejimin finansal sistemi teşvik etmedeki rolü ile ilgili literatürde iki görüş hakimdir. Bunlar demokrasinin ekonomik performans üzerindeki rolünü vurgulayan gelişme teorisi ile baskı grupları, rekabetçi piyasalar ile temel haklar açısından konuyu inceleyen politika ve finans teorisidir. Illk görüşe göre demokratik kurumlar finansal piyasaların verimliliğini artırarak işlem maliyetlerini azaltabilir. Demokratik rejimlerde kamu kaynakları toplumsal ihtiyaçlara daha isabetli bir şekilde yönlendirilmekte, bireysel intiyaçlar, yeni yatırımlar ve dünya ekonomisine entegrasyon ile reel ve finansal piyasalarda performans artışı sağlanabilmektedir (Boudriga ve Ghardallou, 2012: 3). Politika ve 
finans görüşü de siyasi yapı ve politik faktörlerin finansal gelişmeyi belirlemede temel belirleyici faktör olduğunu ileri sürmektedir. Politik faktörler zaman içerisinde sabit olan hukuki köken ve kültüre kıyasla daha sık değişiklik gösterdiklerinden finansal gelişmedeki değişimi daha iyi açıklayabilir (Kupava, 2012: 10). Bu teoriye göre kurumlar ve politikalar, hükümetler tarafından iktidarda kalmalarına ve kaynakları yönetmelerine izin verecek biçimde şekillendirilmektedir. Bu noktada karar alıcılar üzerinde etkili olabilecek baskı grupları ve elitlerin gücü ve amaçları ön plana çıkmaktadır. Eğer elitler serbest ve rakabetçi bir piyasada zenginleşeceklerini düşünüyorlarsa finansal gelişmeyi teşvik edecek yasaları ve kurumları oluşturması için devlete baskı yapacaklardır. Tarihsel olarak daha yaygın olarak karşılaşıldığı şekilde eğer elit tabaka rekabetçi finansal piyasalar tarafından kendilerini tehdit altında hissederlerse, devlete özel işlemleri, dolayısıyla da serbest piyasaları kısıtlama yönünde baskı yapacaklardır. Beck vd. (2001: 3) tarafından belirtildiği gibi merkezi ve güçlü bir devlet elitin çıkarlarını merkezi olmayan, açık ve rekabete dayalı bir politik sistemden daha duyarlı ve etkin bir şekilde yerine getirecektir.

Politika ve finans görüşüne göre finansal kurumların ve piyasaların düzgün işleyişi hükümetin takdir yetkisinde sınırlamalar gerektirmektedir. Bu da merkezi ve güçlü bir devletin hedefleri ile bağdaşmamaktadır. Özellikle finansal gelişme, hükümet üzerinde baskı oluşturan toplumsal kesimlerin gücünü zayıflatmaktadır. Benzer şekilde merkezi ve güçlü bir hükümet iyi işleyen finansal piyasaların temel bileşenlerinden biri olan kamulaştırma yapılmaması ve mülkiyet haklarının ihlal edilmemesini güvenilir şekilde taahhüt edemez. Dolayısıyla merkezi olmayan bir siyasi sistem finansal gelişme için daha elverişli bir çevre sunabilir. Özel çıkar grupları toplumun kalanının zararı pahasına rant sağlamak için hükümetleri zorlayabileceğinden, güçlü grupların çıkarlarını yansıtan hükümetler muhtemelen finansal gelişmeyi daha az destekleyecektir. Benzer şekilde bazı çıkar gruplarının kanun yapıcılar üzerinde etkili olabilmesine izin veren seçim sistemleri, finansal gelişmenin bu çıkar gruplarını tehlikeye düşürmesi durumunda rekabeti ve finansal gelişmeyi teşvik eden yasa ve düzenlemelerin yapılmasını engelleyecektir. (Beck vd., 2001: 20). Politika ve finans görüşü özetle rekabetin az olduğu, ihtiyari davranışlar üzerinde yoğun kontrollerin bulunmadığı merkezi ve kapalı politik sistemlerde finansal sistemlerin, yasama ve yürütme yetkisi üzerinde kontrollerin bulunduğu nispeten ademi merkeziyetçi, açık ve rekabetçi hükümetlerin bulunduğu ülkelerdekinden daha zayıf şekilde geliştiğini belirtmektedir.

Bu konudaki diğer bir argüman reel sektördeki yerleşik firmaların etkisiyle ilgilidir. Rajan ve Zingales (2003: 19) tarafından belirtildiği gibi yerleşik reel sektör firmaları sektöre yeni giriş koşullarını iyileştirdiği, rekabeti artırdığı ve rantları azalttığı için finansal gelişmeyi engelleyebilmekte hatta geriye götürebilmektedirler. Buna göre iş dünyasının elitlerinin ve reel sektördeki yerleşik firmaların sahiplerinin siyasi nüfuzu finansal sektörle ilgili sonuçlar için belirleyicidir. Demokrasi ile otokrasi özellikle de oligarşi arasındaki önemli fark, hesap verebilirliktir. Otokrasilerde hükümet kendi özel çıkarlarını koruyan iş ve siyasetin elitlerinden oluşan dar bir guruba karşı sorumludur. Bu durumda hükümetin amacı yerleşik firmaların rantını korumak olduğundan, kamu politikaları finansal gelişme için engeller yaratacaktır. Demokrasilerde ise hükümet kamu çıkarlarını koruyan yani sosyal refahı artıran tedbirleri almak hususunda kamuoyuna karşı sorumludur. Bu durumda yerleşik firmaların özel çıkarları politikaları şekillendirmediğinden, hükümet finansal gelişmeyi hızlandıran kamu politikalarını tasarlayıp uygulayacaktır. Bu argüman sadece reel sektör için değil yerleşik bankalar için de geçerlidir. Otokrasilerde sadece siyasi bağlantıları olan yatırımcılar projeleri için fon 
sağlayabilmekte ve ilave rant elde edebilmektedirler. Hem reel sektör hem de finans sektöründeki elitlerin sağladığı rantlar siyasi elitle paylaşılmaktadır (Begović vd., 2017: 3).

Politik yapı aynı zamanda kurumların oluşumunda da belirleyicidir. Acemoğlu vd. (2005)'e göre ülkeler arasındaki ekonomik büyüme ve refah farklılıklarının ana kaynağı ekonomik kurumlardaki farklılıklardır. Bunun sebebi ekonomik kurumların toplumdaki temel ekonomik aktörlerin güdülerini şekillendirmesi ve özellikle fiziksel, beşerî sermaye ve teknoloji yatırımları ile üretim organizasyonunu etkilemesidir. Farklı ekonomik kurumlar sadece ekonomik büyüme potansiyelini etkilemekle kalmaz aynı zamanda kaynakların dağılımı (servetin, fiziksel ve beşeri sermayenin dağılımı gibi) dahil bir dizi ekonomik sonucu da etkiler. Diğer bir ifadeyle hem pastanın büyüklüğünü hem de bu pastanın farklı bireyler ve gruplar arasında nasıl paylaşılacağını etkilemektedir. Finansal gelişmenin temel belirleyicilerinden biri olan ekonomik kurumlar iç kaynaklıdır ve ekonomik sonuçlarından dolayı toplumun ortak tercihleri tarafından belirlenmektedir. Bu nedenle kurulacak ekonomik kurumların türleri üzerinde çıkar grupları ve bireyler arasında çatışmalar ortaya çıkabilmektedir. En fazla politik güce sahip olan grubun, kendileri için en fazla yararı sağlayan ekonomik kurumlar kümesini oluşturması muhtemeldir (Voghouei, Azali ve Jamali, 2011: 10). Birbirleriyle karşılaştıııldıklarında ekonomik kurumların etkinliği de bu tercihde rol oynamakla birlikte, politik güç nihai belirleyici olacaktır. Toplumda siyasi gücün dağılımı da içseldir. Acemoğlu vd. (2005) siyasi gücü yasal (kurumsal) ve filli siyasi güç olarak iki bileşene ayırmaktadır. Burada yasal siyasi güç, toplumdaki politik kurumlardan kaynaklanan güce işaret etmektedir. Politik kurumlar ekonomik kurumlara benzer, ancak burada siyasi alanda temel aktörlerin sınırlamaları ve güdüleri belirlenmektedir. Politik kurumlar; yönetim şekli (demokrasi, diktatörlük ya da otokrasi) vasıtasıyla politikacılar ve siyasi elitler üzerindeki sınırlamaların farklı boyutlarını temsil etmektedir. Örneğin monarşide politik kurumlar tüm yasal siyasi gücü krala tahsis eder ve onun uygulamalarına çok az kısıtlama getirir. Buna karşıık anayasal monarşi kralın politik gücünün bir kısmını parlementoya veren, böylece kralın politik gücünü etkin şekilde kısıtlayan politik kurumlara karşılık gelmektedir. Politik kurumlar, ekonomik kurumları ve ekonomik performansı hem doğrudan hem de dolaylı olarak belirlemektedir. Doğrudan etki kapsamında, eğer politik kurumlar tüm siyasi gücü tek bir bireyin ya da küçük bir gurubun elinde toplarsa, mülkiyet haklarını koruyan ve nüfusun geri kalanı için fırsat eşitliği sağlayan ekonomik kurumların sürdürülmesi zordur. Dolaylı etkisi ise şu şekilde çalışmaktadır: politik kurumlar yasal siyasi gücün dağılımını belirler, bu da ekonomik kurum tercihini etkiler, ekonomik kurumlar da ekonomik sonuçları belirlemektedir. Söz konusu ilişki, kurumlar hiyerarşisi olarak adlandırılır (Acemoğlu vd., 2005: 389-391).

Baskı grupları tarafından kontrol edilen ülkeler elitin çıkarlarını toplumun çoğunluğundan korumaya ve politik sisteme katılımı engellemeye daha fazla eğilimlidir. Huang (2010: 1668)'e göre elit grupların sahip olduğu güç arttıkça sistem daha fazla otokratik olmakta ve finansal gelişmenin önündeki engeller de artmaktadır. Bu da politika yapıcılar üzerinde çıkar grubunun etkisini sınırlandırmayı, politik sistemde oy hakkını genişletmeyi, temel siyasi haklara ve sivil özgürlüklere saygı göstermeyi, kurumsal engelleri kaldırmayı ve kurumsal verimliliği artırmayı amaçlayan kurumsal reformun finansal gelişme için faydalı olacağını akla getirmektedir.

Mandon ve Mathonnat (2014: 4-5) siyasi gücün sınırlanması gerektiğine vurgu yaparak demokratik politik kurumların finansal gelişme üzerinde iki temel mekanizma aracılığıyla olumlu bir etkiye sahip olduğunu öne sürmektedirler: (i) siyasi iktidarın takdir yetkisi üzerinde daha fazla sınırlamalar ve (ii) siyasi hakların kademeli olarak genişletilmesi ile karar alma sürecine toplumun daha fazla katılımı. Benzer şekilde finansal gelişmenin politik iktisadı konusundaki 
literatürü özetledikleri çalışmalarında Haber ve Perotti (2008: 48) sınırsız siyasi gücün finansal gelişmeye zarar vereceği sonucuna ulaşmışlardır. Hatta söz konusu araştırmacılara göre hükümetin rolü sınırlı olduğunda dahi bürokrasi gibi bazı yapılar kamu gücünü ele geçirmeye yönelebilmektedir. Ayrıca, otokratik oportünizm, oligopolistik ele geçirme ve demokratik şirketleşme biçimindeki üç farklı politik sınırlamanın finansal sistemin gelişimini ve işleyişini derinden etkilediğini belirtmektedirler.

Bir ülkede hakim politik ve yasal kurumlar büyük ölçüde yönetim biçimine bağlıdır. Demokratik bir ülkede siyasi hayat büyük ölçüde rekabetçidir ve kamu görevlileri halkın oylarıyla seçilmekte ve yasalar tarafından eylemleri kısıtlanmaktadır. Yöneticilerin finans sektöründeki kontrol ve baskısı sınırlandırıldığından, demokrasinin ve rekabetçi bir politik çevrenin etkin bir şekilde finans sektöründe daha yüksek rekabete neden olduğu düşünülmektedir. Ayrıca, demokratik sistemlerin devletin bankalara ve diğer finansal kurumlara sahip olmasını engellediği, dengeleme ve kendini düzeltme mekanizmalarını, açıklığı ve diğer önemli kurumları desteklediği, bu nedenle de finansal gelişme üzerinde pozitif bir etkiye sahip olduğu öne sürülmektedir (Bzhalava, 2014: 2). Bordo ve Rousseau (2006: 19) da parlementer rejim, oy oranına göre temsil ve düzenli yapılan seçimler gibi demokratik kurumların ülkenin uluslararası finans sisteminde mali sorumluluk konusunda itibarını artırabileceğini, dolayısıyla faiz oranlarını azaltarak finansal gelişme vasıtasıyla ekonomik büyümeyi destekleyebileceğini ileri sürmektedirler.

Demokrasi ve finansal gelişme arasındaki nedensellik mekanizması ekonomik kurumların finansal gelişmeye etkisi aracılığıyla başlamaktadır. Mülkiyet haklarının korunmasına, kamulaştırma ve el koyma riskinin azaltılmasına, sözleşme özgürlüğüne ve iş dünyasına yönelik siyasi müdahalelerin engellenmesine katkı sağlayan kurumlar finansal gelişmede önemli rol oynamaktadır. Demokratik sistemlerin, finansal gelişme için önemli olan bu tür kurumsal altyapının oluşturulmasında daha başarılı olduğu ileri sürülmektedir (Begović vd., 2017: 3). Mülkiyet ve bireysel hakların güvence altına alınmasında demokratik kurumların otokratik rejimlerden daha avantajlı olmasının nedeni, mülkiyet haklarını garanti altına almak için gerekli koşulların, sürdürülebilir bir demokrasiye sahip olmak için gerekli koşullarla aynı olmasıdır. Uzun dönemli bir demokrasi medeni hakların korunması şartına bağlıdır. Demokrasi yasal siyasi gücü elitlerden kitlelere yeniden dağıtarak haklarından mahrum kalmış kişiler için güvence oluşturur. Seçim sayesinde en yoksul kesimlere daha fazla güç verileceğinden çoğunluğun çıkarlarına hizmet eden politikalar uygulanabilecektir. Demokrasi rekabeti ve siyasi sisteme katılımı artırarak hükümetin mali piyasayı yönetme ve kontrol etme gücünü sınırlar, rant arayışını azaltır, devletin çıkarlarını vatandaşın tercihlerine göre düzenler, daha istikrarlı bir ortam sağlar ve bu suretle finansal piyasaların etkinliğini artırır (Ghardallou ve Boudriga, 2014: 3).

Özetle, literatürde bazı yazarlar otokrasiyle karşılaştırıldı̆̆ında demokrasi sürecinin temel sivil hakları, politik istikrarı, açık bir toplumu geliştirdiğini, temel hakların korunmasını ve sözleşmelerin uygulanmasını kolaylaştırdığını, yolsuzlukları ve kanunsuzlukları önlediğini, doğrudan yatırımları ve ekonomik büyümeyi teşvik ettiğini ileri sürmektedirler. Bununla birlikte bazı yazarlar ise tam tersine farklı çıkar gruplarından gelen baskılar altında demokratik yapıların karar almada verimsizliğe ve hızlı büyüme için gerekli politikaları uygulamada güçlüklere neden olabileceğini düşünmektedirler. Öyle ki erken demokrasi bazen gelişmekte olan ülkelerde ekonominin büyüme oranını düşürebilmekte, hatta ekonomik düzensizlik, politik istikrarsızlık ve etnik çatışmalarla sonuçlanabilmektedir (Huang, 2010: 1668; Huang, 2011: 103). Ghardallou 
ve Boudriga (2014: 3) da temsile dayalı ve demokratik yönetimlerle ilgili risklere işaret ederek, demokrasilerde populist baskıların bazı olumsuz etkileri bulunduğunu öne sürmüşlerdir. Demokrasi, hızlı tüketim için daha yüksek kamu baskısıyla birleşmiş olduğundan yatırımları engelleyebilmektedir. Ayrıca politika yapıcılarının gelecekteki oyları kazanma isteği hükümeti belirli sektörlerin ve oy bloklarının lehinde politikalar yapmaya zorlayarak kaynakların etkin olmayan şekilde dağılmasına yol açabilecektir. Veto hakkına sahip olan iktidar dışı kesim ise büyümeyi teşvik eden reformları geciktirebilmektedir.

Ancak bu noktada Mandon ve Mathonnat (2014) politik kurumların finansal gelişme üzerindeki etkilerini araştıran çalışmaların çoğunlukla demokrasi ve diktatörlük arasındaki zıtlıkla sınırlı olduğunu belirterek, bunun yeterli olmadığını ileri sürmektedirler. Bu çalışmalarda bir bütün olarak siyasi rejimin finansal gelişme üzerindeki etkisi araştırılmış ve çoğunlukla demokratik rejimlerin finansal gelişme üzerindeki pozitif etkisi vurgulanmıştır. Acemoğlu (2005) tarafından da belirtildiği gibi demokratik rejim kavramı bir takım ekonomik kurumları ve politik kurumları fark gözetmeden biraraya getirir. Bu nedenle Mandon ve Mathonnat (2014: 4)'e göre demokrasi ile finansal gelişme ilişkisini daha iyi anlamak için demokratik rejimlerle ilgili yönetim biçimi (başkanlık, yarı başkanlık, parlamenter sistem), seçim kuralları (çoğunlukçu, karma, oransal) ve devlet şekli (üniter, federal) gibi farklı faktörlerin de araştırılması gerekmektedir.

Yukarıda açıklandığı üzere politik kurumların, politik aktörlerin gelişmeyi sağlamadaki güdülerini nasıl şekillendirdiği konusunda daha ziyade çıkar gruplarının rolüne odaklanılmıştır. Kârlarının azalacağını tahmin eden yerleşik çıkar grupları finansal derinleşmeyi teşvik eden politikalara karşı çıkacaktır. Bununla birlikte çıkar gruplarının yapısına bakılmaksızın hükümet de banka ve kredi piyasalarından kaynakları çekmek için finansal gelişmeyi sınırlandırma eğiliminde olabilir (Bacerra, Cavallo ve Scartascini, 2012: 627). Falahaty ve Hook (2013) tarafından yapılan çalışmada hükümetlerin finansal piyasalara katılımının önemi belirtilerek, hükümetlerin finansal kurumlar aracılığıyla hem finansal hem de ekonomik gelişmeyi başlatabileceği ileri sürülmektedir. Aslında hükümet genellikle yararlı etkilerle kimi zaman ticari bankaların fonksiyonlarını yerine getirmektedir. Politik görüş olarak bilinen diğer görüşe göre ise hükümetin finansal piyasalara katılımı sosyal amaçlardan ziyade politiktir. Bu görüşün savunucularına göre hükümetler oy, siyasi katkı ve rüşvet şeklinde kendilerine geri dönecek destekçilerine istihdam, teşvik ve diğer faydalar sağlamak için işletmeleri ve bankaları kontrol ederler (Falahaty ve Hook, 2013: 49).

Politik ekonomi literatürü siyasi iktidar değişimlerinin de bir ülkenin finansal sistemindeki tarihi değişiklikleri açıklamaya yardımcı olduğunu göstermektedir. Finansal piyasalar servetin, riskin ve gücün dağılımı açısından toplumdaki farklı çıkar grupları üzerinde farklı etkilere sahiptir. Çıkar grupları kendilerine en çok yararı sağlayacak finansal sistemin kurulmasını sağlamak ya da kendilerine zarar verecek finansal sisteme karşı çıkmak için siyasi çoğunluğu kazanmak zorundadır. Siyasi çoğunluk da resmi bir kurum olan seçimler tarafından belirlenmektedir (Degryse, Lambert ve Schwienbacher, 2016: 2). Dolayısıyla seçimler, kabine yapıları, referandumlar ve yasama tartışmaları gibi politik süreçler hükümetlerin ekonomi politikalarını buna bağlı olarak da yatırım ortamının koşullarını belirlemektedir.

Politik altyapının bir diğer unsuru olan politik istikrarsızlık da tasarrufları, yatırımları ve işletme kararlarını etkileyebilmektedir. Politik istikrarsızlık bir ülkedeki hükümetin, rejimin ve toplumun istikrarsızığını kapsadığından üretim faktörlerinin üretim sürecine dahil edilmesi noktasında olumsuz sonuçlar doğurabilir. Politik istikrarsızlık durumunda siyasi rejimlerle birlikte yatırımları düzenleyen politik ve ekonomik kuralların da değişmesi muhtemel 
olduğundan sermaye kaybı riski ve gelecekte elde edilecek getirilerle ilgili belirsizlikler artar. İş dünyası ve hisse senetleri piyasaları başta olmak üzere mali piyasalar seçimler, hükümet yolsuzlukları, işgücü intilafları, kurumsal reformlar ve kamu politikasındaki değişiklikler gibi politik gelişmelerden etkilenmektedir. Hükemetin değişme olasılığının yüksek olması gelecekteki politikalar konusundaki belirsizliği ima ettiğinden riskten kaçınan ekonomik aktörler önemli ekonomik kararlar almaktan kaçınabilir ya da yurtdışına yatırım yapmayı tercih ederek ekonomiden çıkabilirler (Asteriou ve Siriopoulos, 2000: 356). Politik istikrarsızlığın finansal gelişmeyi etkileyip etkilemediği hakkında uygulamalı çalışmalar ise nispeten daha azdır. Eğer iş ortamı konusundaki belirsizlik yatırım talebini azaltırsa, bu fon arzını kolaylıkla etkileyebilir ve daha az finansal varlık tutulmasına, dolayısıyla finansal derinliğin azalmasına neden olur (Bordo ve Rousseau, 2006: 13).

\section{Ampirik Literatür}

Finansal gelişme üzerinde politik faktörlerin etkilerini inceleyen uygulamalı çalışmalar, geniş ülke grupları için standart veri setlerinin oluşturulması ile birlikte özellikle son dönemde artış göstermiştir. Her iki değişken grubunun da zaman içerisinde sınırlı değişim göstermesi nedeniyle, söz konusu çalışmaların büyük kısmı panel veri analizi şeklinde büyük örneklem gruplarını kapsamaktadır. Bu bölümde finansal gelişmenin politik ekonomisi için kanıt arayan seçilmiş uygulamalı çalışmalar iki ana başlık altında incelenmiştir.

İlk olarak, politik sistem ve seçim sisteminin finans piyasaları üzerindeki etkilerinin incelendiği çalışmalar ağırlıklı olarak demokratikleşme düzeyi üzerinde yoğunlaşmaktadır. Temsil oranının yüksek olduğu siyasal sistemlerin finansal gelişmeyi olumlu etkilediğini tespit eden birçok araştırma mevcuttur. Bu çalışmalardan Boudriga ve Ghardallou (2012) kutuplaşmanın pozitif etkiyi artırdığını, ancak olumlu etki için belli seviyede kurumsal altyapının olması gerektiğini ifade etmişlerdir. Girma ve Shortland (2008) ise siyasal rejimin etkisinin hukuk sisteminden daha fazla olduğunu göstermişlerdir. Huang (2010) aynı olumlu etkiyi otoktarik sistemlerden demokrasiye geçen ülkelerde de gözlemlemiştir. Ayadi vd. (2015) politik hesap verme sorumluluğunun kurumsal yapıyı kuvvetlendirdiğini ve finansal gelişmeye katkı sağladığını belirtmişlerdir. Bunun ötesinde Anwar ve Cooray (2012)'ye göre seçmenler için politik haklarının genişletilmesi finansal gelişimin sağladığı avantajları artırmaktadır. Tüm bu bulgulardan farklı olarak Yang (2011) demokratikleşmenin bankacılık sektörü üzerinde pozitif etkisinin olduğu ancak hisse senedi piyasasında gelişme ile ilişkisinin olmadığı sonucuna ulaşmıştır. Siyasal rejimle ilgili bir diğer konu olan sivil ve askeri hükümetlerin finansal sistem ve yatırımcı kararları üzerindeki etkisiyle ilgili yapılan çalışmalarda ise ortak görüş askeri yönetimin borsa performansını düşürdüğü yönünde olmakla birlikte (bkn. Baxter ve Jermann, 1997) reel getirilerin söz konusu iki hükümet durumunda farklı olduğunu reddeden araştırmalar da vardır (örnek olarak Civilize vd., 2015). 
Tablo 1: Politik Faktörlerin Etkisinin Incelendiği Uygulamalı Çalışmalar

\begin{tabular}{|c|c|c|}
\hline Çalışma & Örneklem - Yöntem & Bağımsız Değişken / Etki \\
\hline $\begin{array}{l}\text { Asteriou ve Siriopoulos, } \\
2000\end{array}$ & $\begin{array}{l}\text { Yunanistan, 1960-1995 } \\
\text { OLS }\end{array}$ & $\begin{array}{l}\text { - Sosyopolitik belirsizlik unsurları (-) } \\
\text { (Siyasal cinayetler ve terör, seçimler, demokrasi) }\end{array}$ \\
\hline Anwar ve Cooray, 2012 & $\begin{array}{l}\text { Güney Asya ülkeleri, } \\
\text { 1970-2009, OLS, GMM }\end{array}$ & $\begin{array}{l}\text { - } \text { Siyasal haklar }(+) \\
\text { - } \quad \text { Demokrasi düzeyi }(+) \\
\end{array}$ \\
\hline Ayadi vd. 2015 & $\begin{array}{l}15 \text { ülke, 1985-2009 } \\
\text { FEM, REM }\end{array}$ & - Demokratik yönetim etkileşim katsayısı (+) \\
\hline Beck vd. 2003 & $\begin{array}{l}69 \text { ülke, 1990-1995 } \\
\text { IV, 2SLS }\end{array}$ & $\begin{array}{ll}\text { - } & \text { Politik rekabet }(+) \\
\text { - } & \text { Kontrol ve denge mekanizmaları }(+) \\
\end{array}$ \\
\hline Białkowski vd. 2008 & $\begin{array}{l}27 \text { OECD, } 134 \text { seçim } \\
\text { GARCH }\end{array}$ & $\begin{array}{l}\text { - } \quad \text { Siyasi eğilim değişikliği } \\
\text { - } \quad \text { Parlamento çoğunluğu (+) } \\
\text { - } \quad \text { Oylama kuralları (+) }\end{array}$ \\
\hline $\begin{array}{l}\text { Boudriga ve Ghardallou, } \\
2012\end{array}$ & $\begin{array}{l}110 \text { ülke, 1984-2006 } \\
\text { FEM, REM }\end{array}$ & $\begin{array}{l}\text { - } \text { Demokrasi düzeyi }(-,+) \\
\text { - } \text { Rejimin devamlılığı (+) } \\
\text { - } \text { Siyasal kutuplaşma (+) } \\
\text { - } \quad \text { Siyasal erkin paylaşımı (+) } \\
\end{array}$ \\
\hline Bhattacharyya, 2013 & $\begin{array}{l}96 \text { ülke, 1970-2005 } \\
\text { FEM - GMM }\end{array}$ & $\begin{array}{l}\text { - Demokratik rejimin süresi }(+) \\
\text { - } \quad \text { Demokrasi düzeyi }(+) \\
\end{array}$ \\
\hline Civilize vd. 2015 & $\begin{array}{l}10 \text { gelişen piyasa, } \\
1913-2007, \text { OLS }\end{array}$ & $\begin{array}{l}\text { - } \text { Askeri yönetim (0) } \\
\text { - } \quad \text { Askeri ve sivil yönetimler arası getiri farkı (0) }\end{array}$ \\
\hline Degryse vd. 2016 & $\begin{array}{l}35 \text { ülke, 1830-1999 } \\
\text { OLS, 2SLS }\end{array}$ & • Genişletilmiş oy hakkı (+) \\
\hline Dimic vd. 2015 & $\begin{array}{l}64 \text { ülke, 1990-2013 } \\
\text { FEM }\end{array}$ & $\begin{array}{ll}\text { - } & \text { Politik risk (-) } \\
\text { - } & \text { Politik istikrar tedbirleri }(+) \\
\end{array}$ \\
\hline Döpke ve Pierdzioch, 2006 & $\begin{array}{l}\text { Almanya, 1977-2003 } \\
\text { OLS, VAR }\end{array}$ & $\begin{array}{l}\text { - Hükümet desteği }(+) \\
\text { - Seçim dönemleri }(+) \\
\text { - } \quad \text { Ideoloji (0) } \\
\end{array}$ \\
\hline $\begin{array}{l}\text { Gartner ve Wellershoff, } \\
1995\end{array}$ & $\begin{array}{l}\text { ABD, 1961-1992 } \\
\text { OLS, GLS }\end{array}$ & $\begin{array}{l}\text { - Seçim dönemleri }(+) \\
\text { - } \quad \text { İdeoloji }(0)\end{array}$ \\
\hline Girma ve Shortland, 2008 & $\begin{array}{l}86 \text { ülke, } 1975-2000 \\
\text { OLS, GMM }\end{array}$ & $\begin{array}{ll}\text { - } & \text { Rejimin devamlılığı (+) } \\
\text { - } & \text { Demokrasi düzeyi }(+) \\
\end{array}$ \\
\hline Herger vd. 2008 & $\begin{array}{l}129 \text { ülke, } 1990 \text { 'lar } \\
\text { OLS, 2SLS }\end{array}$ & $\begin{array}{l}\text { - } \quad \text { Yönetsel sınırlar (+) } \\
\text { - } \quad \text { Yasal kurallar }(+) \\
\end{array}$ \\
\hline Huang, 2010 & $\begin{array}{l}90 \text { ülke, } 1960-99 \\
\text { LSDV, GMM }\end{array}$ & - Demokrasiye geçiş (+) \\
\hline Keefer, 2008 & $\begin{array}{l}116 \text { ülke, } 1975-2000 \\
\text { OLS - 2SLS }\end{array}$ & $\begin{array}{ll}\text { - } & \text { Siyasi kontrol mekanizmaları }(+) \\
\text { - } & \text { Rekabetçi seçim sistemi }(+) \\
\text { - } & \text { Kredibilite }(+) \\
\text { - } & \text { Seçmen bilgi düzeyi }(+) \\
\end{array}$ \\
\hline $\begin{array}{l}\text { Mandon ve Mathonnat, } \\
2014\end{array}$ & $\begin{array}{l}140 \text { ülke, 1984-2007 } \\
\text { POLS, FEVD }\end{array}$ & $\begin{array}{ll}\text { - } & \text { Parlamenter yönetim }(+) \\
\text { - } & \text { Federalizm }(+)\end{array}$ \\
\hline Pastor ve Veronesi, 2013 & $\begin{array}{l}\text { ABD, 1985-2010 } \\
\text { OLS }\end{array}$ & - Siyasi belirsizlik (-) \\
\hline Pinto vd. 2010 & $\begin{array}{l}85 \text { ülke, 1975-2004 } \\
\text { OLS }\end{array}$ & $\begin{array}{ll}\text { - } & \text { Iddeoloji (+) } \\
\text { - } & \text { Seçim kuralları (+) } \\
\end{array}$ \\
\hline Roe ve Siegel, 2011 & $\begin{array}{l}85 \text { ülke, 1980-2003 } \\
\text { FEM, IV }\end{array}$ & $\begin{array}{l}\text { - } \text { Politik istikrar (+) } \\
\text { - } \quad \text { Demokrasi düzeyi (-) } \\
\end{array}$ \\
\hline $\begin{array}{l}\text { Voghouei, Azali ve Law, } \\
2011\end{array}$ & $\begin{array}{l}60 \text { ülke, 1980-2006 } \\
\text { OLS, GMM }\end{array}$ & $\begin{array}{l}\text { - } \text { Siyasal güç }(+) \\
\text { - } \quad \text { Politik rekabet (+) }\end{array}$ \\
\hline Yang, 2011 & $\begin{array}{l}151 \text { ülke, 1992-2007 } \\
\text { OLS, GMM }\end{array}$ & - Demokrasi düzeyi (+) \\
\hline
\end{tabular}


Seçim sistemi açısından yapılan çalışmalar incelendiğinde; Keefer (2008)'e göre rekabetçi oylama mekanizmaları ve etkin veto mekanizması finansal gelişimi destekler, benzer sonuca ulaşan Beck vd. (2003) siyasal kontrol araçlarının seçkinlerin politika belirleme gücünü sınırlayıcı özelliğine dikkat çekmektedir. Herger vd. (2008) de yürütme organını kısıtlayıcı düzenlemelerin, yatırımcıları leviathan devlet uygulamalarından koruduğunu ifade etmişlerdir. Degryse vd. (2016) ise oylama mekanizmasının asimetrik sonuçlarına değinmiş, sınırlı oy hakkının azınlıkları koruyarak borsanın gelişmesine uygun ortam oluşturduğunu, ancak genişletilmiş oy hakkının ortanca seçmenin etkisini azaltarak bankacılık sektörünün gelişmesini desteklediğini tespit etmişlerdir. Voghouei, Azali ve Law (2011) politik faktörlerin kurumsallaşmayı, onun da finansal gelişimi teşvik ettiğini; olumlu etkinin kaynağının hükümetlerin yasal politik güçlerinden ziyade siyasi erkin uygulamaları olduğunu göstermişlerdir.

Finansal gelişme üzerinde meclis ve hükümet yapısının etkilerinin incelendiği uygulamalı çalışmalar sınırlıdır. İktidardaki partilerin siyasi yönelimleriyle ilgili yapılan çalışmalardan Pinto vd. (2010) sol ideolojiye sahip iktidar dönemlerinde, yatırımcıların daha az korunduğu şeklindeki geleneksel görüşten farklı olarak finans piyasalarında kapitalizasyon oranının daha yüksek olduğunu savunurken, Döpke ve Pierdzioch (2006) varlık getirilerinin sağ hükümetler döneminde daha yüksek olduğunu iddia etmişlerdir. Białkowski vd. (2008) hisse senedi piyasalarında volatilitenin seçim sonucunda hükümetin siyasi eğilimi değiştiğinde arttığını gözlemlemişlerdir. Aynı çalışmada meclis yapısıyla ilgili bir diğer önemli gösterge olan oy oranları ve sandalye sayısıyla ilgili olarak, hükümetin parlamentoda çoğunluğu sağlayamamasının olumsuz etkilerine dair kanıtlar sunulmuştur. Son olarak merkezi ve yerel idareler arasındaki güç dengesi üzerine yapılan çalışmalardan Mandon ve Mathonnat (2014)'e göre demokratik rejimler, anayasal düzenlemeleri ile siyasi karar alma sürecinde yatay esnekliğe ve dikey istikrara izin veriyorsa finansal gelişimi daha fazla destekleyecektir. Çalışmada geniş bir ülke grubu üzerinde yapılan analizler, mali yerelleşmenin finansal gelişmeyi olumlu etkilediğini göstermiştir.

İkinci alt başlık olan politik istikrar göstergesi olarak literatürde farklı değişkenler kullanılmaktadır. Bunlardan biri olan seçim dönemlerinin finansal piyasalar üzerindeki politik konjonktürel dalgalanmalar anlamında etkileri ile ilgili yapılan uygulamalı çalışmalarda farklı sonuçlar elde edilmiştir. Gartner ve Wellershoff (1995) ABD'de varlık getirilerinin demokrat ve cumhuriyetçi partilerin iktidar dönemlerinde farklılaşmadığını, ancak hükümetlerin görev süresinin ilk yarısında söz konusu getirilerin düşme, ikinci yarısında yükselme eğiliminin olduğunu belirtirken, Döpke ve Pierdzioch (2006) ise Almanya için yaptığı araştırmada seçim dönemlerine yönelik kanıtlar bulamamıştır. Bhattacharyya (2013), konuyu uygulanan siyasal rejimin sürekliliği açısından, Keefer (2008) ise rekabetçi seçimler arasında geçen süre açısından ele almış, her iki çalışmada da politik istikrarın finans piyasaları üzerinde olumlu etkileri tespit edilmiştir. Roe ve Siegel (2011) dört farklı istikrar göstergesi kullanarak yaptıkları analizlerde kurumsal faktörlerin finansal piyasalar üzerinde teşvik edici veya engelleyici nitelikte gücü olduğu, ancak politik istikrarın gerek koşul olduğu sonucuna ulaşmışlardır. Dimic vd. (2015) politik risk unsurlarındaki artışın tüm ülke gruplarında özellikle hisse senedi piyasalarını etkilediğini, olumsuz etkinin en çok hissedildiği ülke grubunun yükselen piyasalar olduğunu ifade etmiştir. Pastor ve Veronesi (2013) ile Asteriou ve Siriopoulos (2000) ise sırasıyla ABD ve 
Yunanistan olarak farklı finansal gelişme düzeylerine sahip ülkeler için yaptıkları analizlerde, siyasal belirsizliğin hisse senedi piyasaları üzerinde güçlü negatif etkisi olduğunu göstermişlerdir.

Yukarıda değinilen uygulamalı çalışmalar politik faktörler ve kurumsallaşma arasındaki ilişkinin finansal gelişme açısından önemine vurgu yapmaktadır. Öyle ki, bir yandan mülkiyet hakları dahi bir kamusal mal olarak siyasal yapıdan etkilenmekte iken diğer yandan rekabetçi ve katılımcı siyasi yapının finans piyasaları üzerinde etki gösterebilmesi için belirli bir düzeyde kurumsal gelişim şarttır.

\section{Az Gelişmiş ve Gelişmekte Olan Ülkelere Yönelik Panel Veri Analizi}

Çalışmada az gelişmiş ve gelişmekte olan 48 ülkede 1985-2012 döneminde politik faktörlerin finansal gelişim üzerindeki etkileri dinamik panel veri yöntemi kullanılarak analiz edilmiştir. Politik faktörlerin etkisi, ülkenin 'politik sistem ve meclis yapısı' ile 'politik istikrar göstergeleri' olarak iki başlık altında incelenecektir. İlk grup değişkenler, o ülkede vatandaşların yönetimde temsil imkânlarının varlığı ve bunun sonucunda ortaya çıkan meclis aritmetiğini ifade ederken, politik istikrar ve/veya istikrarsızlık insanların finansal varlıklar ile daha güvenli kabul edilen fiziksel varlıklara yatırım yapma tercihi açısından önem arzetmektedir.

\subsection{Veri seti}

Çalışmada finansal gelişime etki eden politik faktörlerin tespit edilmesi için politik yapının farklı unsurlarını yansıtan 9 değişken kullanılmıştır. Bunlara ek olarak finansal piyasalar üzerinde etkisi olabilecek değişkenlerin model dışı kalmaması amacıyla dört kontrol değişkeni ile bağımlı değişkenin gecikmeli değeri de modellere eklenmiştir. Değişkenlere ait veriler, politik faktörlerin yıllara yayılan etkileri dikkate alınarak literatürle uyumlu şekilde ve eşit aralıklı olarak dörder yıllık dönem ortalamaları itibariyle analize dâhil edilmişlerdir. Tüm değişkenlere ait tanımlayıcı istatistikler, örneklem grubundaki ülkeler ve veri kaynakları Tablo 2' de sunulmuştur.

Analizde bağımlı değişken olarak finansal gelişim endeksi kullanılmıştır. Levine (2005: 865)'e göre finansal gelişme; finansal sistemin tasarrufları artırma, sermayeyi üretken yatırımlara yönlendirme, yatırımları takip etme, risk dağıtımı, kaynakların mal ve hizmetlere tahsisini kolaylaştırma şeklindeki temel fonksiyonlarında iyileşmeyi gösterebilmelidir. Ampirik çalışmaların birçoğunda veri kısıtı nedeniyle bu çok boyutlu özellik göz ardı edilerek finans piyasalarının derinliği başta olmak üzere finansal gelişimin tek bir boyutu dikkate alınmaktadır. Bu çalışmada ise Svirydzenka (2016) tarafından oluşturulan ve IMF'den sağlanan finansal gelişim endeksi kullanılmıştır. Söz konusu yeni endeks finansal kurumları ve finansal piyasaları derinlik, erişim ve etkinlik açılarından 6 alt başlık çerçevesinde ele alan 20 değişkenden oluşmaktadır. Endeks değerleri 0-1 aralığında normalize edilmiştir. 
Eskişehir Osmangazi Üniversitesi ïBF Dergisi

Tablo 2: Analizde Kullanılan Değişkenler ve Veri Kaynakları

\begin{tabular}{|c|c|c|c|c|c|}
\hline & & Ortalama & Minimum & Maksimum & Kaynak \\
\hline \multicolumn{6}{|c|}{ Bağımlı Değişken } \\
\hline Fin.Gelişim & Finansal Gelişim Endeksi & 0,234 & 0,000 & 0,688 & IMF \\
\hline \multicolumn{6}{|c|}{ Kontrol Değişkenleri } \\
\hline $\ln \mathrm{ISSH}_{\mathrm{t}}$ & Reel GSYH (logaritmik) & 24,37 & 20,524 & 29,139 & WB WDI \\
\hline DışaAçıklıkt & (ihracat+ithalat)/GSYH & 63,54 & 10,748 & 220,40 & WB WDI \\
\hline InEnf ${ }_{t}$ & Tüketici Fiyat End. (log.) & 3,306 & $-17,24$ & 5,097 & IMF \\
\hline Fin. Kriz & Finansal Kriz & 0,088 & 0,000 & 9,000 & IMF \\
\hline \multicolumn{6}{|c|}{ Politik Sistem - Meclis Yapısı } \\
\hline Demokrasi & Rejim Değişkeni & 3,001 & $-9,00$ & 10,00 & Polity IV \\
\hline Yön.Sınır & Yürütmeye Yönelik Kısıtlar & 4,762 & 1,000 & 7,000 & Polity IV \\
\hline Mec.Yapısı & Meclis Yapısı & 1,994 & 0,000 & 3,000 & CNTS \\
\hline Oy.Oranı & Hükümetin Oy Oranı & 36,19 & 0,000 & 100,0 & DPI \\
\hline \multicolumn{6}{|l|}{ Politik İstikrar } \\
\hline Hük.krizi & Hükümet Krizleri & 0,159 & 0,000 & 4,000 & CNTS \\
\hline Kab.Değişim & Kabine Değişim Sıklığı & 0,461 & 0,000 & 4,000 & CNTS \\
\hline Seçim.Dön & Parlamento Seçimleri & 0,236 & 0,000 & 1,000 & DPI \\
\hline Görev.Sür & Hükümet Görev Süresi & 6,822 & 1,000 & 49,00 & DPI \\
\hline Pol.Yolsuzluk & Politik Yolsuzluk Endeksi & 0,573 & 0,033 & 0,943 & V-Dem \\
\hline \multicolumn{6}{|c|}{ Örneklem Grubu } \\
\hline \multicolumn{6}{|c|}{$\begin{array}{l}\text { Arjantin, Bangladeş, Bolivya, Birezilya, Bulgaristan, Çin, Endonesya, Fas, Fildişi Sahilleri, Dominik Cumhuriyeti., } \\
\text { Ekvador Cumh., El Salvador, Etiyopya, Guatemala, Güney Africa, Honduras, Kolombiya, Kosta Rika, Hindistan, İran, } \\
\text { Macaristan, Malavi, Malesya, Mali, Meksika, Mısır, Nijerya, Pakistan, Panama, Peru, Filipinler, Polonya, Romanya, } \\
\text { Ruanda, Senegal, Sierra Leone, Sri Lanka, Şili, Tanzanya, Tayland, Tunus, Türkiye, Uganda, Uruguay, Ürdün, } \\
\text { Venezuela, Vietnam, Zambia, Zimbabve. }\end{array}$} \\
\hline
\end{tabular}

Finansal gelişim üzerinde etkisi araştırılan politik faktörler, (i) politik sistem ve meclis yapısı ile (ii) politik istikrar olarak iki başlık altında incelenecektir. İlk grupta ülkede hakim siyasi rejim, yürütme organının yetkisini sınırlayıcı kurallar, yürütme organının yapısı, hükümetin seçimde aldığı oy oranı yer almaktadır. Birinci değişken olan demokratikleşme düzeyi için Marshall vd. (2017) tarafından Polity IV veriseti kapsamında hesaplanan tümleşik politik skor (Demokrasi) kullanılmıştır. Değişken -10 ile +10 arasında aldığı değer ile ülkede tam otokrasiden yüksek demokratikleşme düzeyine doğru temsil gücünü yansıtmaktadır. Pozitif değerler ile ifade edilen demokrasi düzeyi, seçim sürecindeki rekabet ve seçimlerde vatandaşların politikalar hakkında fikirlerini hangi düzeyde açıklayabildiklerini ölçerken, negatif değerler yönetim kademesinin oluşturulması sürecinde rekabeti önleyici baskı unsurlarını ve katılımcılığı sınırlayan düzenlemeler çerçevesinde otokrasi düzeyini göstermektedir. İkinci değişken benzer bakış açısıyla yürütme gücünü sınırlandırıcı kurallardır (Yön.Sınır.). Yönetsel sınırlamalar üst düzey karar vericilerin yetkilerini kontrol altında tutan kurumsal kısıtlardır. Bu kısıtlar farklı yönetim şekillerinde yasama organı, bağımsız yargı, konsey veya danışma meclisi şeklinde ortaya çıkabilir. Değişken herhangi bir yasal sınırlamanın olmadığı otoriteden, hesap verebilirliği sağlayan yapının idareye eşit veya daha fazla yetkilendirildiği rejimlere doğru 0-7 arasında değerler almaktadır. Illk iki değişken, yönetimin küçük bir elit grupta olmasının toplumda kaynaklara eşit erişim imkânını sınırlandırarak, finansal gelişimi olumsuz etkileyeceği şeklindeki hipotezin test edilmesini amaçlamaktadır. Diğer yandan karar alma yetkisine sahip otoritenin yapısı da önem arz etmektedir. Bu doğrultuda üçüncü olarak meclis yapısı (Mec.Yapısı) değişkeni analize dahil edilmiştir. Değişkenin artan değerleri mühalafetin olmadığı tek parti yönetiminden, hükümetin koalisyon şeklinde olduğu ve mühalefetin de olduğu yapıya doğru değişen meclis yapısını yansıtmaktadır. Son olarak karar alıııların refom yapma gücü ve 
kararlılı̆̆ için kamuoyu desteği gereklidir. Bunun göstergesi olarak çalışmada iktidardaki parti/partilerin seçimde aldıkları toplam oy oranları (Oy.oranı) kullanılmıştır.

Politik faktörlerin ikinci grubunu politik istikrar göstergeleri oluşturmaktadır. Hükümet krizi kukla değişkeni (Hük.krizi) mevcut hükümetin düşürülmesini amaçlayan, rejimi tehdit eden hızla gelişen herhangi bir toplumsal veya ekonomik durumu ifade etmektedir. İkinci değişken kabine değişim sayısıdır (Kab.Değişim). Bir yıl içinde yeni bir başbakanın/başkanın göreve gelmesi ve/veya kabinedeki bakanlardan yarıdan fazlasının değişmesi durumunu göstermektedir. Üçüncü olarak seçim dönemlerinin finansal gelişim üzerindeki etkisi incelenmiştir. Milletvekili seçim yıllarında 1 değeri alan kukla değişken (Seçim.Dön.), politik konjonktürel dalgalanmalar teorisi çerçevesinde incelenen seçim dönemlerinde makroekonomik değişkenlerde ortaya çıkan sapmaları, finansal değişkenler özelinde ele almayı sağlayacaktır. Politik istikrar noktasında üzerinde durulması gereken bir diğer unsur hükümetlerin görev süreleridir. Görev.Sür veri seti bir ülkede hükümetin göreve başladığı yıldan itibaren 1 değeri alarak kümülatif olarak ilerleyen, hükümetin kendi politikalarını herhangi bir müdahale olmadan devam ettirebildiği dönemi kapsamaktadır. Dolayısıyla hükümetlerin darbe vb. sebeplerle görevden alınması, ancak aynı yıl içerisinde iktidara dönmesi durumunda yürütme sürecinin bozulmadığı kabul edilirken, istifa eden ve ardından aynı yıl içerisinde tekrar göreve gelen hükümetler farklı iktidarlar olarak kayda geçmektedir. Analizin son aşamasında siyasi gücün kötüye kullanımının piyasalar üzerindeki etkisini tespit etmek amacıyla politik yolsuzluk endeksi kullanılmıştır (Pol.Yolsuzluk). Politik yolsuzluk endeksi yürütme, yasama ve yargı organları ile genel kamu kurumları olmak üzere dört farklı alanda rüşvet, hırsızlık vb. yolsuzluk göstergelerinin eşit ağırlıklı ortalamaları ile türetilmiştir. Yasama meclisinin olmadığı durumlarda diğer üç alt bileşimin ortalaması alınmıştır. Yüksek endeks değerleri yüksek yolsuzluk düzeyine işaret etmektedir.

Şekil 2: Seçilmiş Göstergelerin Dönem Içerisindeki Seyri

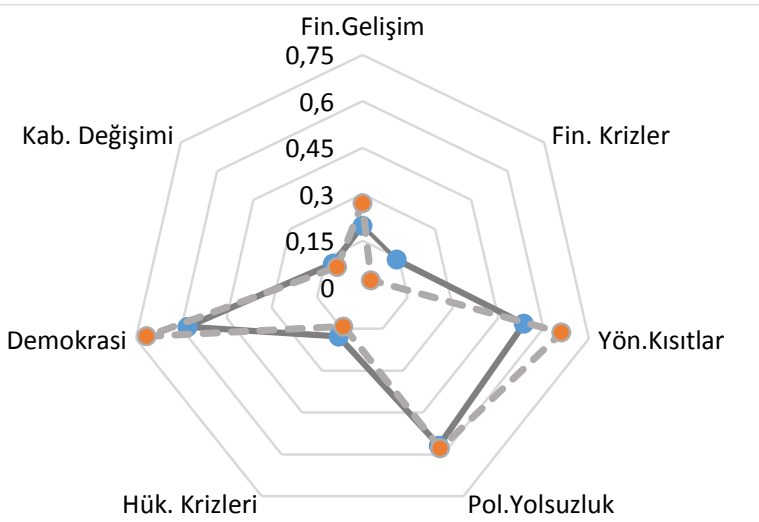

Notlar: Grafikte düz çizgi analiz döneminin ilk yarısındaki, kesikli çizgi ikinci yarısındaki ortalama değerleri göstermektedir. Kukla değişkenler dışındaki değişkenler 0-1 düzeyinde normalize edilmiştir. Veri kaynakları için bkn. Tablo 2.

Bağımlı değişken ve seçilmiş açıklayıcı değişkenlerin analiz dönemi içerisindeki seyri Şekil 2'de görülmektedir. Gelişen piyasalarda 1980 sonrası finansal gelişmişlik düzeyinde belirgin bir artış yaşanırken düşük gelirli gelişmekte olan ülkelerde daha sınırlı bir yükselme seyri söz konusudur. Dönemin ilk yarısı ile karşılaştırıldığında, demokrasi düzeyi ve buna paralel şekilde yürütme organına yönelik yasal sınırlamalar belirgin şekilde artmıştır. Hükümet krizlerinin 
görülme sıklığında 1999 sonrası dönemde sınırlı bir azalma yaşanırken asıl önemli değişim finansal krizlerdeki azalmadır. Kabine değişim hızı ve politik yolsuzluk endeksinde ise dönem boyunca önemli bir değişim yaşanmamıştır. Yolsuzluk ise halen gelişmekte olan ülkelerde yüksek düzeyiyle etkin kamu yönetimi önünde engel olmaya devam etmektedir.

Modelde kontrol değişkenleri vektörü dört açıklayıcı değişkenden oluşmaktadır. Finansal sistem üzerinde doğrudan veya dolaylı etkileri göz önüne alınarak bu değişkenler; reel sektörü temsilen reel GSYH, dış piyasaları ve uluslararası mal ve döviz hareketlerini temsilen dışa açıklık oranı, ulusal para politikasının önceliklerini göstermesi anlamında enflasyon oranı ve ekonomik şoklar için finansal kriz değişkenidir. Reel GSYH (InrGSYH) ilgili literatürde hemen her modelde ekonomik performansı, sermaye birikimini, finansal hizmetlere yönelik artan talebi, kalkınma ve kurumsal gelişimi (Beck vd. 2003) temsilen yer almaktadır. Dışa açıklık oranı (DışaAçıklık), yine yaygın olarak kullanılan toplam mal ihracat ve ithalatının GSYH'ye oranı şeklinde alınmıştır. Daha genel bir gösterge olarak her bir ülke için küreselleşme endeksi yerine bu verinin alınmasının nedeni, potansiyel içsellik probleminin önlenmesidir. Makroekonomik yapının bir diğer göstergesi olarak enflasyonun da (tüketici fiyat endeksinin logaritmik değeri şeklinde) etkileri incelenmiştir (InEnf). Zira enflasyon özellikle bankacilık sektörünün gelişimi ve hisse senedi piyasalarındaki faaliyetlerin temel belirleyicilerinden birisidir (benzer çalışmalara örnek olarak Dimic vd. 2015; Boyd vd. 2001). Son olarak kamuoyunda geniş çaplı güven kaybına neden olan, yatırım kararlarını ve risk algısını değiştirerek finansal gelişimi olumsuz etkileyebilecek bir faktör olarak finansal krizler (Girma ve Shortland, 2008) modele dahil edilmiştir (Fin.Kriz). Laeven ve Valencia (2012) tarafından derlenen veri seti sistematik bankacılık krizleri, para krizleri ve kamu borç krizlerini kapsamaktadır. Söz konusu krizler başlangıç aşamasında nominal değişkenlerde önemli sapmalara neden olmakta, krize müdahale aşamasında ise özellikle para politikalarında ciddi değişimleri beraberinde getirmektedir.

\subsection{Yöntem}

Birçok makroekonomik değişkende olduğu gibi finansal gelişmişlik düzeyi de birikimli bir süreci ifade ettiğinden geçmiş dönem değerlerine duyarlıdır. Dolayısıyla bu çalışmada politik faktörlerin finansal gelişme üzerindeki etkisinin tespit edilmesi amacıyla Huang (2010), Girma ve Shortland (2008) vb. çalışmalarda takip edilen metodolojiye uygun olarak aşağıdaki dinamik panel veri modeli tahmin edilmiştir:

$$
y_{i t}=\propto y_{i, t-1}+\beta x_{i t}+\gamma z_{i t}+\eta_{i}+v_{i t}
$$

Denklemde $y_{i t}$ bağımlı değişken finansal gelişim endeksini, $x_{i t}$ politik faktörlerin yer aldığı açıklayıcı değişken grubunu, $z_{i t}$ kontrol değişkenleri matrisini, $\eta_{i}$ ülkeye özgü zamana göre değişmeyen gözlemlenemeyen etkileri ve $v_{i t}$ hata terimini temsil etmektedir. Ancak yukarıdaki modelin en küçük kareler ile yapılan parametre tahminleri, bağımsız değişkenin ihmal edilen sabit etkiler ile pozitif ilişkili olan gecikmeli değerleri nedeniyle sapmalı ve tutarsız olacaktır. Zira $Y_{t-1}{ }^{\prime}$ in bağımsız değişken olarak modele dahil edilmesi, en küçük kareler yönteminin açıklayıcı değişkenlerin hata terimi ile korelasyonunun olmaması şeklindeki temel varsayımını ihlal etmektedir. Dinamik modellerde GLS tahmincileri de sapmalı olduğundan söz konusu modellerin tahmininde araç değişkenlerin kullanılması önerilmektedir. Roodman (2009: 86)'ya göre bu soruna çözüm olarak önerilen genelleştirilmiş momentler methodu zaman boyutunun kesit boyutundan küçük olduğu veri setlerinde, bağımlı değişkenin dinamik özellikler gösterdiği ve açıklayıcı değişkenlerin katı dışsalıı koşulunu sağlamadığı durumlarda, değişen varyans ve otokorelasyon sorunlarının kesitler arasında değil her bir kesit boyutunda ortaya çıktığı örneklemlerde kullanılabilmektedir. Arellano ve Bond (1991) tarafından geliştirilen fark-GMM 
tahmincisi tutarlı ve benzer bir çözüm sunan iki aşamalı en küçük kareler yöntemine göre asimtotik olarak daha etkin olmasına rağmen, sınırlı örneklem grupları için sapmalı sonuçlar türetebileceğinden Arellano ve Bover (1995) ve Blundell ve Bond (1998) tarafından sistemGMM tahmincisi önerilmiştir. Sistem-GMM yaklaşımı araç olarak bağımlı değişken, açıklayıcı değişkenler ve kontrol değişkenlerinin uygun gecikmeli değerlerinin kullanıldığı fark denklemleri ile bunların birinci farklarının gecikmeli değerlerinin kullanıldığı düzey denklemlerini bir araya getirmektedir. Bu şekilde artırılan araç değişken sayısı etkinliği de artırır. GMM analizlerinde tek aşamalı tahmin, hata terimlerinin kesitler arasında ve zaman içinde sabit varyanslı olduklarını kabul ederken, iki aşamalı tahmin hata terimlerinin değişen varyanslı olabileceğini hesaba katarak daha tutarlı varyans-kovaryans matrisi sağlamaktadır (Doornik ve Hendry, 2001). Çalışmada bu avantajından dolayı iki aşamalı tahmin yöntemi kullanılmıştır.

\subsection{Bulgular}

Analiz sonuçlarında katsayıların yorumlanmasından önce, ilk aşamada modellerin geçerliliğini sınayan test istatistiklerinin incelenmesi gerekir. Tüm modellerde Wald test sonuçları modellerin bir bütün olarak anlamlı olduğunu göstermektedir. GMM analizlerinde araç değişken sayısının kesit sayısından küçük olması koşulu dokuz modelde de sağlanmaktadır. Araç değişkenlerin geçerliliği, düzeltilmiş standart hatalar kullanıldığı için Hansen J istatistiği ile test edilmiştir. Olasılık değerlerine göre tüm modellerde araç değişkenlerin geçerli olduğu şeklindeki $\mathrm{H}_{\mathrm{o}}$ hipotezinin reddedilememiş olması, araç değişkenlerin kalıntılarla ilişkisiz olduğunu göstermektedir. Son olarak hata terimlerinde ardışık bağımlılık sorunu araştırılmış, $A R(2)$ test istatistiği sonuçlarına göre yine tüm modellerde ikinci dereceden otokorelasyon probleminin olmadığı tespit edilmiştir.

Yukarıda yapılan açıklamalar doğrultusunda seçilmiş politik faktörlerin finansal gelişme üzerindeki etkisi Tablo 3.A ve Tablo 3.B'de dokuz model halinde raporlanmıştır. Politik sistem ve meclis yapısını karakterize eden değişkenleri içeren ilk tabloda birinci model, uygulanan siyasal rejimin finansal gelişim üzerindeki etkisini incelemektedir. Rejim için kullanılan değişken özelliği itibariyle farklı demokrasi ve otokrasi düzeylerinde simetrik olmayacağından, olası doğrusal olmayan etkinin tespiti için modele ilgili değişkenin karesi de dahil edilmiştir. Demokrasi değişkeni tahmin katsayısı negatif işaretli ve anlamlı, demokrasi değişkeninin karesinin katsayısı ise pozitif ve anlamlıdır. Ampirik literatür kısmında da değinildiği gibi mevcut çalışmalar ağırlıklı olarak (Girma ve Shortland, 2008; Anwar ve Cooray, 2012 vb.) demokratikleşme düzeyinin yükselmesinin finansal gelişimi teşvik ettiği sonucuna ulaşmışlardır. Literatürdeki uygulamadan farklılık arzeden buradaki yaklaşım ve elde edilen sonuçlar ise, ülkede otokrasiden demokrasiye doğru yaşanan geçiş sürecinde finansal gelişimin önce olumsuz etkilendiğini, demokratikleşme seviyesi arttıkça finansal gelişimin de arttığını ifade etmektedir. Rejim değişimlerinin neden olduğu toplumsal gerilim ve belirsizlik (Huang, 2010) dikkate alındığında bu sonuç beklentilerle uyumludur.

Model II yürütme organının yetkilerini sınırlayan kurum ve kuralların finansal gelişim üzerindeki etkisini araştırmaktadır. Politik kurumsallaşmayı temsil eden değiş̧enin katsayısı pozitif olmakla birlikte istatistiksel olarak anlamlı değildir. Beck vd. (2003), Herger vd (2008) ve Keefer (2008)'in yürütme organının keyfi davranışlarına potansiyel olarak kısıtlamalar getiren kurumsal düzenlemelerin ve kontrol mekanizmalarının finansal gelişime destek olacağı şeklindeki sonuçlarının istatistiksel olarak teyit edilememesinin olası bir nedeni, bu çalışmadaki örneklem grubunun yalnızca az gelişmiş ve gelişmekte olan ülkelerden oluşmasından dolayı kurumsal yapının bir bütün olarak işlevini yerine getirememesi olabilir. Sonraki model mecliste 
yürütme organının koalisyon şeklinde ortaya çıktığı bir yapının finans piyasalarının gelişimi için olumsuz etkisini ima etmektedir. Birden fazla partiden oluşan hükümetlerde uzun dönemde etkisini gösterecek reformların hayata geçirilmesi daha zor hale gelmekte, iktisat politikalarında değişim yaşanmaktadır. Örneğin Tabellini ve Alesina (1990) kabinedeki parti sayısının artmasının genişletici maliye politikaları uygulama eğilimini ve bütçe açıklarını artırdığını ifade etmektedir. Dolayısıyla makroekonomik performansta ortaya çıkan bozulma, yatırımcıların risk alma eğilimlerini değiştirmektedir. Uygulamalı çalışmalar bu sonucu teyit etmekte, bunun da ötesinde koalisyonu oluşturan parti sayısının artmasının belirsizliği artırarak finansal istikrarsızlığı derinleştirdiğini göstermektedir (bkn. Białkowski vd. 2008). Benzer bir durum iktidardaki hükümetin oy oranı için de geçerlidir. Model IV'te elde edilen sonuçlara göre hükümetin oy oranında artış finansal gelişimi pozitif ve istatistiksel olarak anlamlı şekilde etkilemektedir. Zira hükümetlerin parlamentoda çoğunluğu sağlayamaması, bir yandan politika yapıcıların kamuoyu desteğinin ve kredibilitesinin düşük olması anlamına gelmekte, diğer yandan yapısal reformlara yönelik düzenlemelerin parlamentodan geçmesini zorlaştırmaktadır.

Tablo 3:. Iki Aşamalı Sistem-GMM Analiz Sonuçları Politik Sistem ve Meclis Yapısı Finansal Gelişim

\begin{tabular}{|c|c|c|c|c|}
\hline & Model I & Model II & Model III & Model IV \\
\hline \multirow[t]{2}{*}{ Fin.Gelişim ${ }_{\mathrm{t}-1}$} & $0,508^{* * *}$ & $0,652^{* * *}$ & $0,340^{* * *}$ & $0,423^{* * *}$ \\
\hline & $(0,136)$ & $(0,115)$ & $(0,148)$ & $(0,114)$ \\
\hline \multirow[t]{2}{*}{$\ln r G S Y H_{t}$} & $0,035^{* * *}$ & $0,023^{* * *}$ & $0,045^{* * *}$ & $0,037^{* * *}$ \\
\hline & $(0,012)$ & $(0,008)$ & $(0,014)$ & $(0,008)$ \\
\hline \multirow[t]{2}{*}{ DışaAçıklıkt } & $0,096^{* * *}$ & $0,060^{* *}$ & $0,119^{* * *}$ & $0,073^{* *}$ \\
\hline & $(0,029)$ & $(0,030)$ & $(0,043)$ & $(0,036)$ \\
\hline \multirow[t]{2}{*}{$\ln E n f_{t}$} & $0,011^{* *}$ & 0,002 & 0,017 & $0,021^{* * *}$ \\
\hline & $(0,005)$ & $(0,002)$ & $(0,007)$ & $(0,006)$ \\
\hline \multirow[t]{2}{*}{ Fin.Krizt } & 0,007 & $-0,025$ & $-0,027^{* * *}$ & $-0,009$ \\
\hline & $(0,017)$ & $(0,016)$ & $(0,036)$ & $(0,027)$ \\
\hline \multirow[t]{2}{*}{ Demokrasit ${ }_{t}$} & $-0,011^{* * *}$ & - & - & - \\
\hline & $(0,003)$ & & & \\
\hline \multirow[t]{2}{*}{ Demokrasi ${ }^{2} t$} & $0,001^{* *}$ & - & - & - \\
\hline & $(0,001)$ & & & \\
\hline \multirow[t]{2}{*}{ Yön.Sınır ${ }_{t}$} & - & 0,011 & - & - \\
\hline & & $(0,171)$ & & \\
\hline \multirow[t]{2}{*}{ Mec.YapısIt } & - & - & $-0,106^{* * *}$ & - \\
\hline & & & $(0,038)$ & \\
\hline \multirow[t]{2}{*}{ Oy.oranıt } & - & - & - & $0,002^{* *}$ \\
\hline & & & & $(0,001)$ \\
\hline Gözlem & 279 & 278 & 279 & 279 \\
\hline Wald test ist. & $170^{* * *}$ & $378^{* * *}$ & $94^{* * *}$ & $270^{* * *}$ \\
\hline Araç Değ. Sayısı & 31 & 31 & 31 & 31 \\
\hline$A R(2)$ test prob. & 0,709 & 0,948 & 0,201 & 0,152 \\
\hline Hansen test prob. & 0,280 & 0,072 & 0,336 & 0,441 \\
\hline
\end{tabular}

Notlar: 48 ülke, 1985-2012. Araç değişken olarak bağımlı değişkenin ve açıklayıcı değişkenlerin gecikmeli değerleri kullanılmıştır. Modellerde istatistiksel olarak anlamlı sabit bulunmakta olup tabloda raporlanmamıştır. Değişen varyansa göre düzeltilmiş standart hatalar katsayı tahminlerinin altında parantez içerisinde sunulmuştur. Standart hatalar Windmeijer sınırlı örneklem ayarlamasına göre yeniden hesaplanmıştır. ${ }^{* *}, * *$ * ${ }^{*}$ sırasıyla $\% 1, \% 5$ ve $\% 10$ düzeyinde katsayıların istatistiksel olarak anlamlı olduğunu göstermektedir.

Tablo 3.B'de politik istikrarı temsilen kullanılan beş faktörün finansal piyasaların gelişimi üzerindeki etkileri incelenmiştir. Model V'de elde edilen sonuçlara göre hükümet krizleri finansal piyasaları \%1 anlamlılık düzeyinde negatif etkilemektedir. Siyasi krizler bir bütün olarak 
ekonomiyi olumsuz etkilediğinden finansal varlıklara olan tabeli azaltır. Diğer yandan, hükümet krizleri ardından birçok öngörülemeyen risk unsurunu beraberinde getirebileceğinden, yatırımcılar tarafından bir eşik olarak kabul edilebilir. Her ne kadar 1980 sonrasında darbe ve iç savaşlar önceki dönemlere göre azalmış olsa da (Roe ve Siegel, 2011: 284), bu seviyeye ulaşmayan ağır siyasi istikrarsızlıklar halen finansal piyasalar için belirleyici bir faktör olmaya devam etmektedir. Kabine değişim sıklığı da finansal piyasalar için önemli bir belirsizlik unsurudur. Kabine değişiminin nedeni seçimler, güvenoyu, piyasa güveninin yeniden kazanılması, başkan/başbakanın ölümü gibi önceden tahmin edilebilecek veya edilemeyecek farklı nedenlerden kaynaklansa da nihayetinde ekonomik karar birimlerinin, politikacıların zaman ufku ve gelecekteki iktisat politikalarıyla ilgili tahminlerini değiştirmektedir. Model VI'da Kab.Değişimit değişkeninin katsayısı negatif ve anlamlıdır. Küresel çapta finansal varlıklara yönelik yatırımlar ulusal pazarların maruz kaldığı risklere göre değerlendirildiğinden (Asteriou ve Siriopoulos, 2000: 371), özellikle gelişen piyasalarda politik risk, yabancı fonların ülkeye çekilmesi ve finansal varlıkların getirisini etkilemektedir.

Tablo 4: Iki Aşamalı Sistem-GMM Analiz Sonuçları Politik istikrar - Finansal Gelişim

\begin{tabular}{|c|c|c|c|c|c|}
\hline & Model V & Model VI & Model VII & Model VIII & Model IX \\
\hline \multirow[t]{2}{*}{ Fin.Gelişim ${ }_{\mathrm{t}-1}$} & $0,677^{* * *}$ & $0,615^{* * *}$ & $0,701^{* * *}$ & $0,634^{* * *}$ & $0,576^{* * *}$ \\
\hline & $(0,106)$ & $(0,123)$ & $(0,135)$ & $(0,102)$ & $(0,084)$ \\
\hline \multirow[t]{2}{*}{$\mathrm{InrGSYH}_{t}$} & $0,032^{* * *}$ & $0,022^{* *}$ & $0,032^{* * *}$ & $0,029^{* * *}$ & $0,026^{* * *}$ \\
\hline & $(0,007)$ & $(0,010)$ & $(0,007)$ & $(0,006)$ & $(0,004)$ \\
\hline \multirow[t]{2}{*}{ DışaAçıklıkt } & 0,034 & $0,069^{* *}$ & $0,071^{* * *}$ & $0,069^{* * *}$ & $0,058^{* * *}$ \\
\hline & $(0,025)$ & $(0,034)$ & $(0,025)$ & $(0,022)$ & $(0,022)$ \\
\hline \multirow[t]{2}{*}{$\ln E n f_{t}$} & $-0,001$ & $-0,001$ & 0,002 & 0,003 & $0,007^{* * *}$ \\
\hline & $(0,004)$ & $(0,005)$ & $(0,004)$ & $(0,002)$ & $(0,002)$ \\
\hline \multirow[t]{2}{*}{ Fin.Kriz $z_{t}$} & $-0,001^{* *}$ & $-0,046$ & $-0,021$ & $-0,022$ & $-0,010$ \\
\hline & $(0,017)$ & $(0,044)$ & $(0,024)$ & $(0,014)$ & $(0,019)$ \\
\hline \multirow[t]{2}{*}{ Hük.krizit } & $-0,161^{* * *}$ & - & - & - & - \\
\hline & $(0,062)$ & & & & \\
\hline \multirow[t]{2}{*}{ Kab.Değişim ${ }_{t}$} & - & $-0,277^{* *}$ & - & - & - \\
\hline & & $(0,118)$ & & & \\
\hline \multirow[t]{2}{*}{ Seçim.Dön.t } & - & - & $-0,424^{* * *}$ & - & - \\
\hline & & & $(0,141)$ & & \\
\hline \multirow[t]{2}{*}{ Görev.Sür.t } & - & - & - & 0,001 & - \\
\hline & & & & $(0,001)$ & \\
\hline \multirow[t]{2}{*}{ Pol.Yolsuzluk } & - & - & - & - & $-0,481^{* * *}$ \\
\hline & & & & & $(0,130)$ \\
\hline Gözlem & 279 & 279 & 279 & 279 & 285 \\
\hline Wald test ist. & $361^{* * *}$ & $515^{* * *}$ & $812^{* * *}$ & $424^{* * *}$ & $287^{* * *}$ \\
\hline Araç Değ. Sayısı & 31 & 31 & 31 & 31 & 31 \\
\hline $\mathrm{AR}(2)$ test prob. & 0,692 & 0,251 & 0,997 & 0,700 & 0,921 \\
\hline Hansen test prob. & 0,138 & 0,313 & 0,108 & 0,094 & 0,163 \\
\hline
\end{tabular}

Notlar: 48 ülke, 1985-2012. Araç değişken olarak bağımlı değişkenin ve açıklayıcı değişkenlerin gecikmeli değerleri kullanılmıştır. Modellerde istatistiksel olarak anlamlı sabit bulunmakta olup tabloda raporlanmamıştır. Değişen varyansa göre düzeltilmiş standart hatalar katsayı tahminlerinin altında parantez içerisinde sunulmuştur. Standart hatalar Windmeijer sınırlı örneklem ayarlamasına göre yeniden hesaplanmıştır. ***, **. * sırasıyla \%1, \%5 ve \%10 düzeyinde katsayıların istatistiksel olarak anlamlı olduğunu göstermektedir.

Politik istikrarla ilgili olarak etkisi incelenen üçüncü açıklayıcı değişken seçim dönemleridir. Regresyon tahmin sonuçlarında parlamento seçimleri için kullanılan kukla değişkenin katsayısı negatif ve anlamlıdır. Dolayısıyla finansal piyasalar parlamento aritmetiğinde değişim anlamına gelen seçim dönemlerinden olumsuz etkilenmektedir. Gelişmekte olan ülkelerde seçim 
dönemlerinin düzenli olmaması, belirsizliği artırmaktadır. Ayrıca Białkowski vd. (2008: 1947)'nin de belirttiği gibi seçimler, aynı zamanda finansal piyasalarda volatiliteyi artırmaktadır. Özellikle herhangi bir partinin tek başına yüksek bir oy oranı ile iktidara gelme ihtimalinin kamuoyunca düşük görüldüğü seçimlerde, uzun veya başarısız bir koalisyon oluşturma süreci veya hükümetin politik yönünün değişme ihtimali olduğu durumlarda söz konusu etki artmakta ve daha uzun sürmektedir. İdarenin görev süresinin bağımlı değişken üzerindeki etkisi Model VIII'de incelenmiş, katsayı beklentilere uygun olarak pozitif olmakla birlikte anlamlı bir etki tespit edilememiştir. Söz konusu değişkenin gelişmiş ülkeler üzerine yapılan analizlerde anlamlı bir etkisi olmasına rağmen gelişmekte olan ülkelerden benzer sonuçların elde edilememesi, bu ülkelerde uzun dönemli totaliter yönetimlerin varlığı ile açıklanabilir. Son olarak Model IX'da görüldüğü gibi politik yolsuzluk düzeyinde artış finansal gelişimi engellemektedir. Yolsuzluk endeksinin politik istikrar çerçevesinde ele alınmasının nedeni, bu tür görevi kötüye kullanma durumlarının ortaya çıkmasının karar alıılara karşı kamuoyu desteğini azaltması, hatta iktidarda değişime neden olabilmesidir.

Sonuçlarda demokrasi, yürütme organının yetkilerini sınırlayan düzenlemeler, iktidarın görev süresi değişkenleri için elde edilen bulguların, analizlerde gelişmiş ülke gruplarının da yer aldığı çalışmalardan farklı olması, finansal gelişme üzerinde siyasi mekanizmanın farklı dinamiklerinin etkili olduğuna, strateji ve politikaların belirlenmesinde ülkelere özgü değerlendirmeler yapılması gerektiğine işaret etmektedir. Analizlerde kullanılan kontrol değişkenleri için parametre tahminleri incelendiğinde ise; finansal gelişimin geçmiş değerlerine ve reel GSYH artışına güçlü şekilde duyarlı olduğu görülmektedir. Tahmin edilen modellerden bir tanesi dışında diğerlerinde ticari dışa açıklık finansal gelişimi pozitif ve anlamlı olarak etkilemektedir. Bu sonuç, ticari açıklığın yatırımcıları leviathan hükümete karşı koruyucu fonksiyonunu, hisse senedi fiyatlarını artırıcı etkisini, faiz marjlarını önemli ölçüde azaltıcı etkisi yoluyla finansal piyasaların büyümesini sağlayıcı etkilerini doğrulamaktadır. Enflasyon değişkeninin ise anlamlı ve tüm modellerde tutarlı bir etkisi tespit edilememiştir. Finansal şokları temsil eden kukla değişkenin tahmin edilen katsayıları negatif işaretli olmakla birlikte yalnızca iki modelde istatistiksel olarak anlamlıdır.

\section{Sonuç}

Politik yapı ile finansal gelişim ilişkisi, ülkeler arası finansal gelişim ve dolaylı olarak ekonomik performans farklılıklarının açıklanmasına katkı sağlayabilecek disiplinler arası bir araştırma konusudur. Özellikle kurumsal altyapının tamamlanamadığı az gelişmiş ve gelişmekte olan ülkelerde siyasetin ekonomi üzerindeki etkisi artmaktadır. Bu ülkelerde para ve sermaye piyasalarında; gönüllü tasarrufların düşük olması, dış kaynaklara bağımlılık, kronik dış ticaret açığının ulusal para birimi üzerindeki baskısı, risk priminin yüksek olması gibi uzun dönemde reformları gerektiren yapısal sorunlar mevcuttur. Ancak temsil gücü zayıf ve merkeziyetçi kamu yönetim anlayışı, hükümetlerin ortalama görev süresinin kısa olması, yüksek yolsuzluk düzeyi ve siyasi krizler bu ülkelerde toplumsal taleplere göre şekillenen uzun dönemli politikaların uygulanmasına engel olmaktadır.

Bu çalışmada az gelişmiş ve gelişmekte olan ülkelerde finansal gelişim üzerinde politik yapının farklı boyutlarını yansıtan dokuz değişkenin etkileri dinamik panel veri yöntemi ile araştırılmış, söz konusu değişkenlerden yedi tanesinin anlamlı etkisi olduğu tespit edilmiştir. Politik sistem ve meclis yapısı kapsamında gerçekleştirilen analizlerden elde edilen sonuçlar demokrasi düzeyinin düşük olduğu ülkelerde temsil gücündeki artışın finansal gelişmeyi olumsuz etkilediğini, temsil gücü arttıkça etkinin pozitif hale geldiğini göstermiştir. Diğer 
göstergelerde ise hükümetin yüksek oy oranı ile seçilmesinin finansal gelişimi olumlu, koalisyon şeklindeki hükümet yapısının ise olumsuz etkilediği, yürütme organının yetkilerini sınırlayan kurum ve kuralların ise anlamlı bir etkisinin olmadığı sonucuna ulaşılmıştır. Politik istikrar açısından bakıldığında siyasi krizlerin, kabine değişim sıklığının, milletvekili seçim dönemlerinin ve politik yolsuzluk düzeyinin finansal gelişimi engellediği tespit edilmiş, hükümetin görev süresinin etkisine dair anlamlı bulgular elde edilememiştir.

Elde edilen sonuçlar karar alıcılar ve karar alma mekanizmalarının önemini vurgulayarak politikalara yönelik bazı çıkarımlar yapma imkânı sağlamaktadır. Illk olarak kurumsal altyapısını tamamlayamamış olan az gelişmiş ve gelişmekte olan ülkelerde demokratikleşme sürecinin neden olduğu toplumsal anlamdaki sancılı geçiş süreci finansal piyasaları da etkilemektedir. İkincisi uzun dönemli bir olgu olan finansal gelişim, ancak yapısal reformları gerçekleştirebilecek güçlü hükümetlerce sağlanabilir. Üçüncü olarak gelişmekte olan piyasalar için politik risk ekonomik karar birimleri için temel belirleyicilerden birisidir. Fon arz ve talep edenlerce öngörülemeyen politik istikrarsızlığa neden olan gelişmeler, finansal piyasalar üzerinden reel ekonomiyi ve toplam refahı etkilemektedir. Zira bu durum yabancı kaynaklara bağımlılık, büyük yatırımların finanse edilememesi, yüksek risk primleri ve borçlanma maliyetinde artış şeklinde tüm ekonomiye yayılacaktır. Son olarak idari sistemde yapısal sorunlara işaret eden politik yolsuzluk, hükümete duyulan güveni ve desteği azaltarak yatırım kararlarını etkilemektedir. 


\section{Eskişehir Osmangazi Üniversitesi IïB Dergisi}

\section{Kaynaklar}

Acemoglu, Daron; Simon Johnson; Robinson, James (2005), "Institutions as a Fundamental Cause of Long-Run Growth", Handbook of Economic Growth, (Ed. Philippe Aghion ve Steven N. Durlauf), Vol. 1A., Chapter 6, Elsevier: 386-472.

Anwar, Sajid; Cooray, Arusha (2012), "Financial Development, Political Rights, Civil Liberties and Economic Growth: Evidence from South Asia”, Economic Modelling, Vol. 29, No. 3: 974-981.

Arellano, Manuel; Bond, Stephen (1991), "Some Tests of Specification for Panel Data: Monte Carlo Evidence and an Application to Employment Equations", Review of Economic Studies, Vol. 58: 277-297.

Arellano, Manuel; Bover, Olympia (1995), “Another Look at The Instrumental Variable Estimation of Error-Components Models", Journal of Econometrics, Vol. 68: 29-51.

Asteriou, Dimitrios; Siriopoulos, Costas (2000), "The Role of Political Instability in Stock Market Development and Economic Growth: The Case of Greece", Economic Notes by Banca Monte dei Paschi di Siena Spa, Vol. 29, No. 3: 355-374.

Ayadi, Rym; Arbak, Emrah; Naceur, Sami Ben; De Groen W. Pieter (2015), "Determinants of Financial Development Across the Mediterranean", Economic and Social Development of the Southern and Eastern Mediterranean Countries, (Ed. Ayadi R., Dabrowski M., De Wulf L.), Springer: Cham: 159-181.

Baxter, Marianne; Jermann, Urban (1997), "The International Diversification Puzzle is Worse than You Think", American Economic Review. Vol. 87, No.1: 170-180.

Becerra, Oscar; Cavallo, Eduardo; Scartascini, Carlos (2012), "The Politics of Financial Development: The Role of Interest Groups and Government Capabilities", Journal of Banking\&Finance, Vol. 36, No.3: 626-643.

Beck, Thorsten; Demirgüç-Kunt, Aslı; Levine, Ross (2001), "Law, Politics, and Finance”, Policy Research Working Paper No: 2585, World Bank, Washington DC.

Beck, Thorsten; Demirgüç-Kunt, Aslı; Levine, Ross (2003), “Law, Endowments, and Finance”, Journal of Financial Economics, Vol. 70, No.2: 137-181.

Begović, Boris; Mladenović, Zorica; Popović, Danica (2017), “Democracy, Financial Development, and Economic Growth: An Empirical Analysis", CLDS Working Paper, WP No. 0317.

Bhattacharyya, Sambit (2013), "Political Origins of Financial Structure”, Journal of Comparative Economics, Vol. 41, No. 4: 979-994.

Białkowski, Jędrzej; Gottschalk, Katrin; Wisniewski, Tomasz Piotr. (2008), "Stock Market Volatility Around National Elections", Journal of Banking \& Finance, Vol. 32, No. 9: 1941-1953.

Blundell, Richard; Bond, Stephen (1998), "Initial Conditions and Moment Restrictions in Dynamic Panel Data Models", Journal of Econometrics, Vol. 87: 115-143.

Bordo, Michael D.; Rousseau, Peter L. (2006), "Legal-Political Factors and The Historical Evolution of the FinanceGrowth Link", NBER Working Paper Series, No: 12035.

Boudriga, Abdelkader; Ghardallou, Wafa (2012), “Democracy and Financial Development: Does the Institutional Quality Matter" First draft, https://pdfs.semanticscholar.org/3193 (Erişim 21.06.2018).

Boyd, John H.; Levine, Ross; Smith, Bruce D. (2001), "The Impact of Inflation on Financial Sector Performance”, Journal of Monetary Economics, Vol. 47, No. 2: 221-248.

Bzhalava, Eri (2014), Determinants of Financial Development, Master Thesis, Charles University in Prague, Faculty of Social Sciences, Institute of Economic Studies, Prague.

Civilize, Sireethorn; Wongchoti, Udomsak; Young, Martin (2015), "Military Regimes and Stock Market Performance", Emerging Markets Review, Vol. 22: 76-95.

Degryse, Hans; Lambert, Thomas; Schwienbacher, Armin. (2016), “The Political Economy of Financial Systems: Evidence from Suffrage Reforms in the Last Two Centuries", Economic Journal, Vol. 128, No. 611: 1433-1475.

Dimic, Nebojsa; Orlov, Vitaly; Piljak, Vanja (2015), "The Political Risk Factor in Emerging, Frontier, and Developed Stock Markets", Finance Research Letters, Vol. 15: 239-245.

Doornik, Jurgen; Hendry, David F (2001), Modelling Dynamic Systems Using PcGive 10, Timberlake Consutants.

Döpke, Jörg; Pierdzioch, Christian (2006), "Politics and The Stock Market: Evidence from Germany", European Journal of Political Economy, Vol. 22, No. 4: 925-943.

Falahaty, Manizheh; Hook, Law Siong (2013), "The Determinants of Financial Development: New Evidence from the Middle East and North Africa Region”, Journal of Economic Cooperation \& Development, Vol. 34, No. 3: 35-60. 
Gärtner, Manfred; Wellershoff, Klaus W (1995), "Is There an Election Cycle in American Stock Returns?”, International Review of Economics \& Finance, Vol. 4, No. 4: 387-410.

Ghardallou, Wafa; Boudriga, Abdelkader (2014), "Financial Development and Democracy is the Relationship NonLinear?", The Economic Research Forum (ERF) Working Paper Series, No: 886.

Girma, Sourafel; Shortland, Anja (2008), "The Political Economy of Financial Development", Oxford Economic Papers, Vol. 60, No. 4: 567-596.

Haber, Stephen; Perotti, Enrico (2008), "The Political Economy of Financial Systems", Tinbergen Institute Discussion Paper, 045/2.

Herger, Nils; Hodler, Roland; Lobsiger, Michael. (2008), “What Determines Financial Development? Culture, Institutions or Trade", Review of World Economics, Vol. 144, No. 3: 558-587.

Huang, Yongfu (2010), "Political Institutions and Financial Development: An Empirical Study", World Development, Vol. 38, No. 12: 1667-1677.

Huang, Yongfu (2011), Determinants of Financial Development, Palgrave Macmillan UK.

Keefer, Philip (2008), "Beyond Legal Origin and Checks and Balances: Political Credibility, Citizen Information, and Financial Sector Development", Political Institutions and Financial Development, (Eds. Haber, S., North, D., Weingast, B.), Stanford University Press: Stanford, CA: 125-155.

Kupava, Anton (2012), The Political Economy of Access to Finance: The Case of Belarus, Master Thesis, Department of Economics Tilburg University.

Laeven, Luc; Valencia, Fabian (2012), Systemic Banking Crises Database: An Update. IMF Working Paper WP/12/163.

La Porta, Rafael; Lopez-de-Silanes, Florencio; Shleifer, Andrei; Vishnyi Robert (1998), "Law and Finance”, Journal of Political Economy, Vol. 106, No. 6: 1113-1155.

La Porta, Rafael; Lopez-de-Silanes, Florencio; Shleifer, Andrei; Vishnyi Robert (1997), "Legal Determinants of External Finance", The Journal of Finance, Vol. LII, No. 3: 1131-1150.

Levine, Ross (2005), "Finance and Growth: Theory and Evidence", Handbook of Economic Growth, (Ed. Philippe Aghion \& Steven Durlauf), Chapter 12, Elsevier: 865-934.

Mandon, Pierre; Mathonnat, Clément (2014), Forms of Democracies and Financial Development. Etudes et Documents, No 21, CERDI. http://www.cerdi.org/ (Erişim tarihi: 14.04.2018)

Marshall, Monty; Jaggers, Keith; Gurr, Ted (2017), Political Regime Characteristics and Transitions, 1800-2016, Dataset and Data-set Users Manual; http://www.cidcm.umd.edu/

Pástor, L'uboš; Veronesi, Pietro. (2013), "Political Uncertainty and Risk Premia”, Journal of Financial Economics, Vol. 110, No. 3: 520-545.

Pinto, Pablo M.; Weymouth, Stephen; Gourevitch, Peter (2010). "The Politics of Stock Market Development", Review of International Political Economy, Vol. 17, No. 2: 378-409.

Rachdi, Hoessem; Mensi, Sami (2012), “Does Institutions Quality Matter for Financial Development and Economic Growth Nexus? Another Look at the Evidence from MENA Countries", The Economic Research Forum Working Paper Series, No: 705.

Rajan, Raghuram G.; Zingales, Luigi (2003), "The Great Reversals: The Politics of Financial Development in the Twentieth Century”, Journal of Financial Economics, Vol. 69: 5-50.

Raza, Syed Hassan; Shahzadi, Hina; Akram, Misbah (2014), “Exploring the Determinants of Financial Development (Using Panel Data on Developed and Developing Countries)", Journal of Finance and Economics, Vol. 2, No. 5: 166172.

Roe, Mark J.; Siegel, Jordan I. (2011), "Political Instability: Effects on Financial Development, Roots in The Severity of Economic Inequality", Journal of Comparative Economics, Vol. 39, No. 3: 279-309.

Roodman, David (2009), "How to do xtabond2: An Introduction to Difference and System Gmm in Stata", The Stata Journal, Vol. 9, No. 1: 86-136.

Svirydzenka, Katsiaryna (2016). Introducing a New Broad-Based Index of Financial Development. International Monetary Fund. WP.16/05

Tabellini, Guido; Alesina, Alberto (1990), "Voting on the Budget Deficit", American Economic Review, Vol. 80, No. 1: 37-49. 
Eskişehir Osmangazi Üniversitesi ïBF Dergisi

Voghouei, Hatra; Azali, M.; Law, Siong Hook (2011), “Does The Political Institution Matter for Financial Development?”, Economic Papers: A Journal of Applied Economics and Policy, Vol. 30, No. 1: 77-98.

Voghouei, Hatra; Azali, M.; Jamali, Mohammad Ali. (2011), "A Survey of The Determinants of Financial Development", Asian-Pacific Economic Literature, Vol. 25, No. 2: 1-20.

Yang, Benhua (2011), “Does Democracy Foster Financial Development? An Empirical Analysis”, Economics Letters, Vol. 112, No. 3: 262-265. 